\title{
Contribution of human Fc $\gamma$ Rs to disease with evidence from human polymorphisms and transgenic animal studies
}

\author{
Caitlin Gillis $^{1,2 \dagger}$, Aurélie Gouel-Chéron ${ }^{1,2,3 \dagger}$, Friederike Jönsson ${ }^{1,2}{ }^{* \neq}$ and Pierre Bruhns $s^{1,2} * \neq$ \\ 1 Laboratoire Anticorps en Thérapie et Pathologie, Département d'Immunologie, Institut Pasteur, Paris, France \\ 2 U760, INSERM, Paris, France \\ ${ }^{3}$ Department of Anesthesia and Intensive Care, Hospital of Bichat-Claude Bernard, Public Assistance-Hospitals of Paris, Paris, France
}

\section{Edited by:}

Jan Terje Andersen, Oslo University

Hosiptal, Norway

Reviewed by:

Beatrice Jahn-Schmid, Medical

University of Vienna, Austria

Sylvie Fournel, Strasbourg University,

France

\section{${ }^{*}$ Correspondence:}

Friederike Jönsson and Pierre Bruhns,

Laboratoire Anticorps en Thérapie et

Pathologie, Département

d'Immunologie, Institut Pasteur, 25

rue du Docteur Roux, Paris 75015,

France

e-mail: joensson@pasteur.fr;

bruhns@pasteur.fr

${ }^{+}$Caitlin Gillis and Aurélie

Gouel-Chéron have contributed

equally to this work.

${ }^{\ddagger}$ Friederike Jönsson and Pierre

Bruhns are Co-senior authors.
The biological activities of human IgG antibodies predominantly rely on a family of receptors for the Fc portion of IgG, Fc $\gamma R$ R: Fc $\gamma R I$, Fc $\gamma R I I A$, Fc $\gamma R$ RIIB, Fc $\gamma R$ RIIC, Fc $\gamma R$ RIIIA, Fc $\gamma$ RIIIB, FcRL5, FcRn, and TRIM21. All Fc $\gamma$ Rs bind IgG at the cell surface, except FcRn and TRIM21 that bind IgG once internalized. The affinity of Fc $\gamma$ Rs for $\lg G$ is determined by polymorphisms of human Fc $\gamma$ Rs and ranges from $2 \times 10^{4}$ to $8 \times 10^{7} \mathrm{M}^{-1}$. The biological functions of Fc $\gamma R s$ extend from cellular activation or inhibition, IgGinternalization/endocytosis/phagocytosis to $\lg G$ transport and recycling. This review focuses on human Fc $\gamma$ Rs and intends to present an overview of the current understanding of how these receptors may contribute to various pathologies. It will define Fc $\gamma$ Rs and their polymorphic variants, their affinity for human IgG subclasses, and review the associations found between Fc $\gamma R$ polymorphisms and human pathologies. It will also describe the human Fc $\gamma$ R-transgenic mice that have been used to study the role of these receptors in autoimmune, inflammatory, and allergic disease models.

Keywords: IgG receptors, transgenic mice, anaphylaxis, autoimmune diseases, genetic polymorphisms and disease association, human $\lg \mathrm{G}$ receptors

\section{INTRODUCTION ON HUMAN Fc $\gamma$ Rs: DEFINITION AND BASIC FUNCTIONS}

Human myeloid cells, NK cells, and B cells are equipped with a variety of receptors that enable their interaction with monomeric or aggregated immunoglobulins, antigen-antibody immune complexes, and opsonized (antibody-coated) particles, cells, or surfaces. Most of these receptors bind the Fc portion of immunoglobulins (receptors for the Fc portion of immunoglobulins, FcR) and endow these cells with the capacity to interact with $\operatorname{IgM}$, IgA, $\operatorname{IgG}$, and/or IgE. This review will focus on IgG-binding human FcRs, Fc $\gamma$ Rs.

Humans express nine Fc $\gamma$ Rs: the six classical Fc $\gamma$ Rs, Fc $\gamma R I$, Fc $\gamma$ RIIA, Fc $\gamma$ RIIB, Fc $\gamma$ RIIC, Fc $\gamma$ RIIIA, and Fc $\gamma$ RIIIB; as well as FcRn, FcRL5 (1, 2), and TRIM21 (3) (Figure 1). These Fc $\gamma$ Rs all bind IgG on the surface of the cells expressing them, except FcRn $(4,5)$ and TRIM21 $(6,7)$ that bind IgG once internalized. Notably, all $\operatorname{IgG}$ receptors bind at least two human $\operatorname{IgG}$ subclasses, albeit with varying binding affinity: the association constants $\left(\mathrm{K}_{\mathrm{A}}\right)$ of $\operatorname{IgG}-\mathrm{Fc} \gamma \mathrm{R}$ interactions range from $8 \times 10^{7}$ down to $2 \times 10^{4} \mathrm{M}^{-1}$ (8) (Figure 1). Historically, Fc $\gamma$ Rs were categorized as either low-affinity receptors that can only bind IgG when present in an immune complex, aggregated, or opsonized; or highaffinity receptors that can also bind free or monomeric IgG. This terminology has become rather obsolete considering reports of high- and low-affinity interactions for a single receptor toward different Ig subclasses. Furthermore, although the prevailing belief was that occupancy of high-affinity receptors with pre-bound monomeric IgG prevents their participation in immediate IgGdependent reactions; this has recently been refuted in vivo (9). Adding to this complexity, human Fc $\gamma$ R polymorphisms that modulate affinity for some human IgG subclasses have been described (8) (refer to part 2; Figure 1).

Human Fc $\gamma$ R expression on different cell types has been fairly comprehensively described, mostly by the use of Fc $\gamma \mathrm{R}$-specific monoclonal antibodies ( $\mathrm{mAb}$ ) but also from data using mRNA profiling (Figure 2). Generally, the following observations can be made: $\mathrm{hFc} \gamma \mathrm{RI}$ (CD64) is restricted to monocytes/macrophages and dendritic cells and is inducibly expressed on neutrophils (10) and mast cells (11); hFc $\gamma$ RIIA (CD32A) is expressed on all myeloid cells but not on lymphocytes; hFc $\gamma$ RIIB (CD32B) is expressed at high levels only on B cells (12) and basophils (13). It is also expressed on tissue macrophages and dendritic cells (12), but only at low levels on $20 \%$ of circulating monocytes and $4 \%$ of circulating neutrophils $(12,14)$, and is not expressed on primary skin mast cells (15); hFc $\gamma$ RIIC (CD32C; refer to Section "Human Fc $\gamma$ R Polymorphisms" for its "stop 13 " polymorphism) is expressed on NK cells (16), monocytes, and neutrophils (17); hFc $\gamma$ RIIIA (CD16A) is expressed on NK cells and monocytes/macrophages; $\mathrm{hFc} \gamma \mathrm{RIIIB}(\mathrm{CD} 16 \mathrm{~B})$ is highly expressed on neutrophils and at low levels on some basophils (18). TRIM21 (aka Ro52) was described 


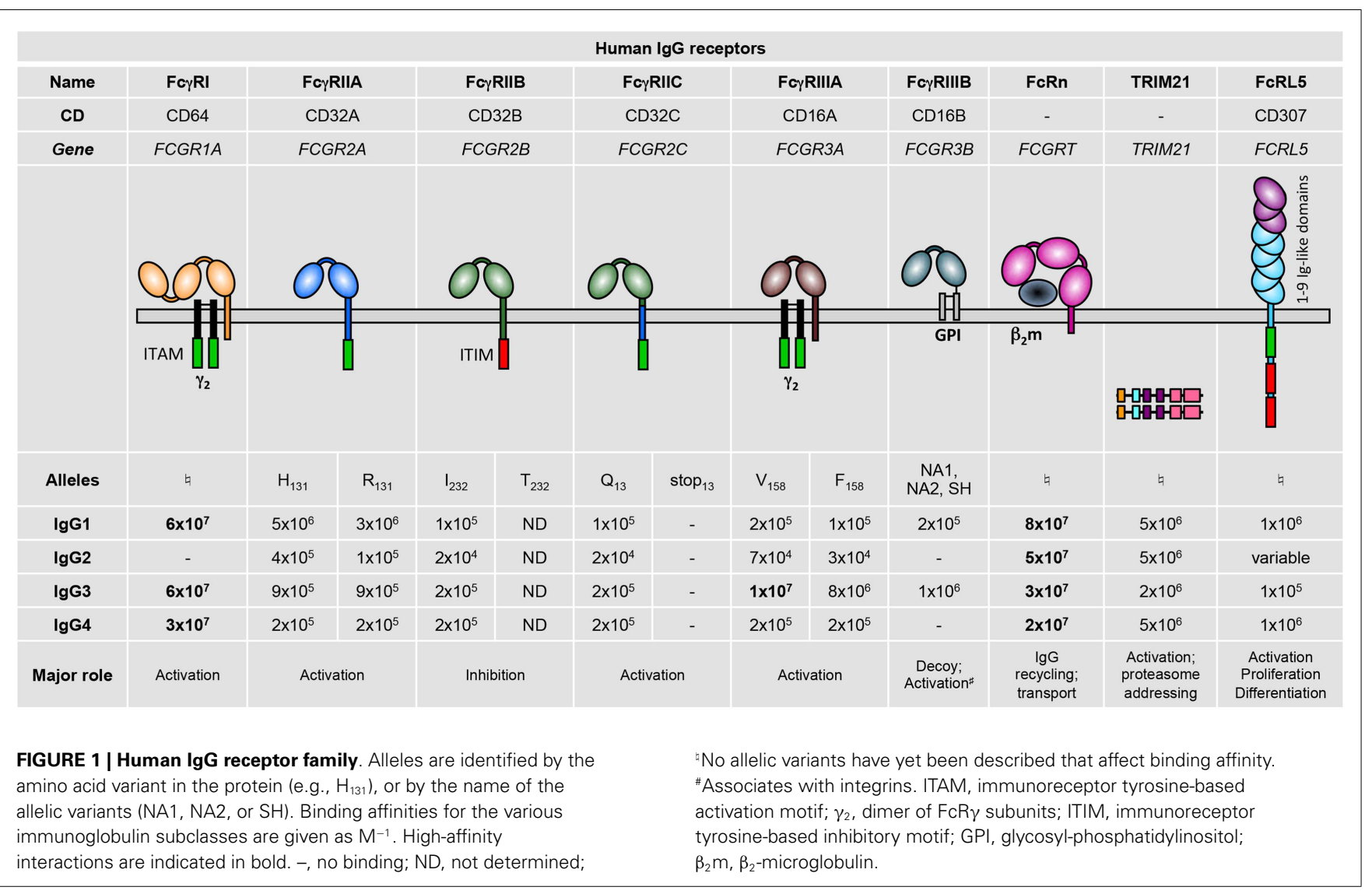

to be widely expressed among lymphoid and myeloid populations, but also on endothelial cells (19). FcRL5 has been reported to be restricted to B cells (2).

These expression patterns highlight that hFc $\gamma$ RIIA is the only activating IgG receptor constitutively expressed by mast cells, basophils, neutrophils, and eosinophils, and that FCRL5 is the only activating IgG receptor constitutively expressed by B cells. Importantly, signal transduction events induced by human activating IgG receptors may be negatively regulated by hFc $\gamma$ RIIB only in B cells, dendritic cells, and basophils, and rare fractions of monocytes and neutrophils. Indeed, mast cells, NK cells, and most neutrophils and monocytes do not express this inhibitory receptor. hFcRn has been reported in dendritic cells, monocytes/macrophages (21), neutrophils (22), and endothelial cells (23), but expression on platelets and mast cells has not been examined so far.

These patterns correspond to the expression of Fc $\gamma$ Rs in healthy individuals. These may be modified during pathological conditions or following therapeutic treatments. Certain cytokines for example have been reported to up-regulate or down-regulate some hFc $\gamma$ Rs; e.g., B cells express higher levels of hFc $\gamma$ RIIB following IFN- $\gamma$ but lower levels following IL-4 stimulation, whereas opposite effects have been reported for monocytes [reviewed in Ref. (24)]. On the latter cells, expression of hFc $\gamma$ RIIA is increased following IFN- $\gamma$ and decreased following IL-4 stimulation (25). IL-3 stimulation, however, induces higher expression of both receptors (activating hFc $\gamma$ RIIA and inhibitory hFc $\gamma$ RIIB) on basophils
(13). Mucosal mast cells express hFc $\gamma$ RI upon IFN- $\gamma$ stimulation (11). Surprisingly, IL-3 stimulation of primary monocytes did not modify $\mathrm{hFc} \gamma \mathrm{RI}$ expression, but increased its ability to bind IgG-immune complexes and to induce intracellular activation signals (26).

Activating Fc $\gamma$ Rs signal through an immunoreceptor tyrosinebased activation motif (ITAM) that is either present in their intracytoplasmic domain or in associated signaling subunits, such as the FcR $\gamma$ chain (Figure 1), the $\operatorname{FcR} \beta$ chain (exclusively in mast cells and basophils), or the $\mathrm{CD} 3 \zeta$ chain (exclusively in NK cells). These ITAM-containing structures allow Fc $\gamma$ Rs, once aggregated by multimeric ligands, to activate signaling cascades via SRC family kinases and spleen tyrosine kinase (SYK) leading to cell activation, cytokine/chemokine production, and cell migration (27-29). The inhibitory receptor Fc $\gamma$ RIIB possesses instead an immunoreceptor tyrosine-based inhibition motif (ITIM) in its intracytoplasmic domain (30), which allows this receptor, once co-engaged with an activating $\mathrm{Fc} \gamma \mathrm{R}$, to recruit the inositol polyphosphate-5-phosphatase SHIP1 (31) that counteracts the signaling cascades initiated by activating Fc $\gamma$ Rs (24). FcRL5 possesses both an ITAM and two ITIMs; however, it has been reported to exert mainly negative regulatory functions (32). IgG receptors devoid of both ITAM and ITIM may induce cell activation by associating with other receptors at the cell membrane, for example the glycophosphatidylinositol-anchored Fc $\gamma \operatorname{RIIIB}(33,34)$ associates with integrins (35); or by activating transcription pathways or proteasome-related mechanisms as does $\operatorname{TRIM} 21(7,36)$. 


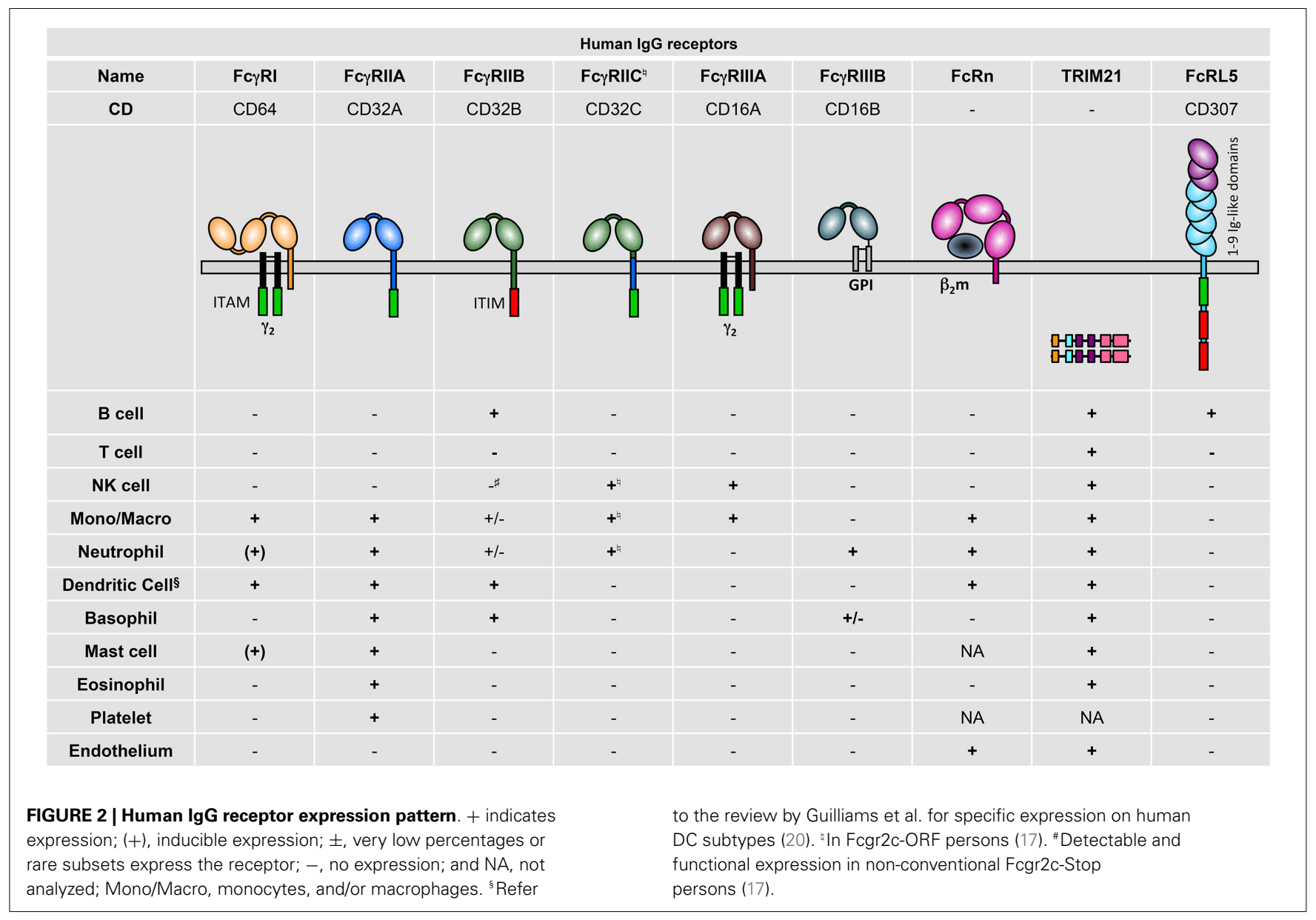

Internalization of antibodies, and of the antigens they are bound to, represents the only shared function of IgG receptors expressed at the cell surface (that is, all except FcRn and TRIM21), whether ITAM-bearing, ITIM-bearing, or neither. Fc $\gamma$ Rs thereby enable antigen capture and internalization by all $\mathrm{Fc} \gamma \mathrm{R}$-expressing nucleated cells, as well as phagocytosis of opsonized bacteria, viruses, or cells by phagocytes. FcRn is the only receptor enabling transcytosis of IgG or IgG-IC by polarized cells (23). Enhanced uptake of antibody-bound antigen enables antigen-presenting cells to activate antigen-specific $\mathrm{T}$ cells considerably more efficiently than free antigen (37), signifying the pivotal role of $\mathrm{Fc} \gamma \mathrm{Rs}$ in the initial phase of humoral and cellular immune responses. Receptors that bind IgG only when it has already been internalized, FcRn (the topic of this review series) and the ubiquitously expressed intracellular receptor TRIM21, may possibly contribute to this phenomenon [reviewed in Ref. (20)].

\section{HUMAN FC $\gamma$ R POLYMORPHISMS DEFINITIONS}

The multiplicity of human Fc $\gamma$ Rs (Figure 1) is increased by a series of genetic polymorphisms, for which we will describe herein only those leading to known functional modifications. These are summarized in Table 1.

\section{FC $\gamma R$ RIIA}

A polymorphism resulting in the presence of a histidine or an arginine residue at position 131 may also be referred to as low-responder $\left(\mathrm{H}_{131}\right)$ or high-responder $\left(\mathrm{R}_{131}\right)$ (38). The Fc $\gamma$ RIIA- $\mathrm{H}_{131}$ allotype was originally reported to allow binding to IgG2 (53), subject to ethnic variation $(54,55)$, and was later described to also have increased binding for IgG3 (39). More recently, we have identified that only the binding to IgG1 and IgG2 are increased for $\mathrm{H}_{131}$ compared to $\mathrm{R}_{131}$ (8).

A novel splice variant of FCGR2A, Fc $\gamma$ RIIA-exon $6^{*}$, containing an expressed cryptic exon $6^{\star}$ was identified in 2013 (41), and is associated with increased neutrophil sensitivity to IgG stimulation (56).

\section{$F C \gamma R I I B$}

Single-nucleotide polymorphisms (SNPs) at positions 386 [IIB$386(\mathrm{G} / \mathrm{c})$ ] and 120 [IIB-120 (T/a)], collectively constitute the 2B.4 promoter haplotype, which displays increased binding capacity for transcription factors GATA4 and Yin-Yang1, resulting in increased promoter activity and higher expression of Fc $\gamma$ RIIB on monocytes, B lymphocytes, neutrophils, and myeloid DCs $(24,42)$.

A polymorphism encoding an isoleucine to threonine substitution at position 232 in the transmembrane domain of Fc $\gamma$ RIIB $\left(\mathrm{T}_{232}\right)$ may disable receptor function via exclusion from lipid rafts $(43,57)$.

\section{Fc $\gamma R$ RIIC}

In $20 \%$ of individuals FCGR2C encodes for a glutamine at position $13\left(\mathrm{Q}_{13}\right.$ or ORF) and Fc $\gamma$ RIIC is expressed; but in $80 \%$ of 
Table 1 | Summary of human Fc $\gamma$ R polymorphisms.

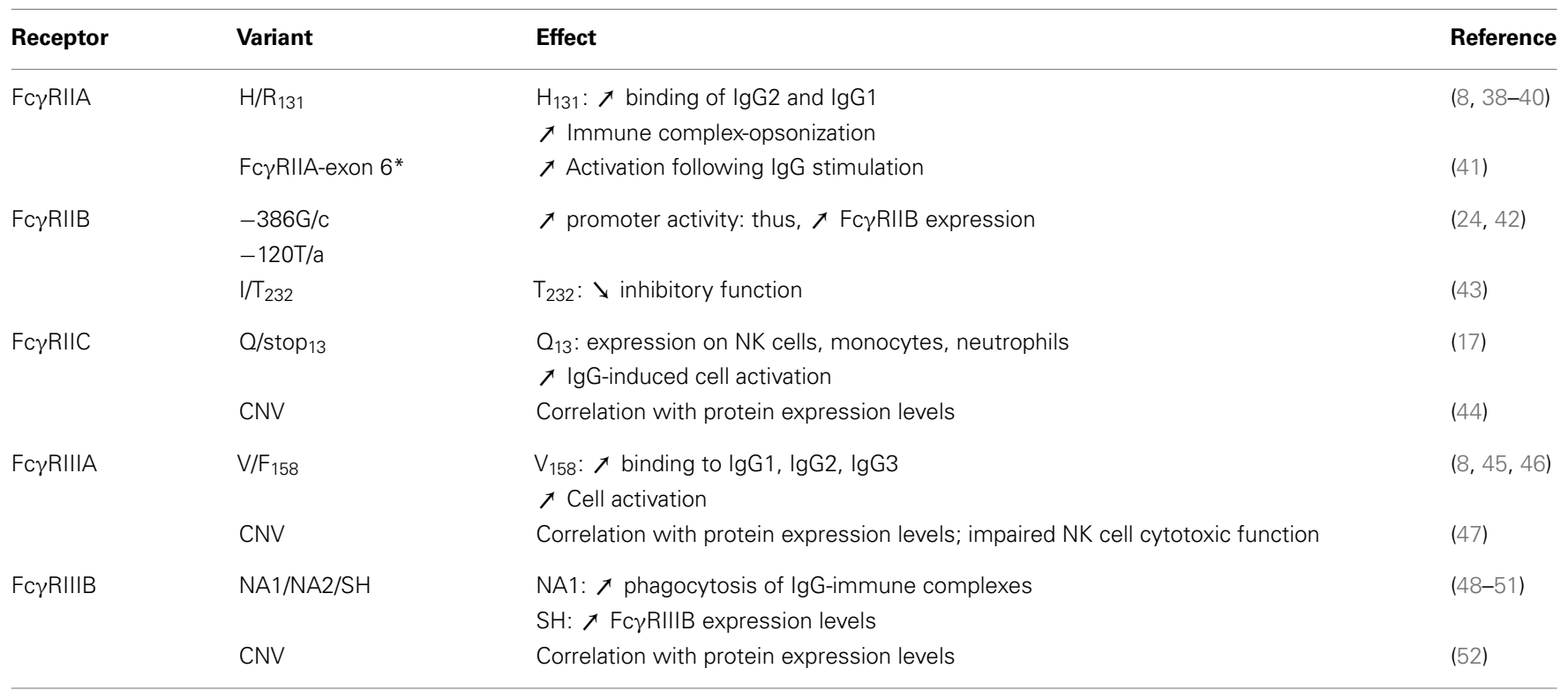

individuals a SNP generates a stop codon $\left(\right.$ stop $\left._{13}\right)$, in which case FCGR2C represents a pseudogene (16).

A subset of individuals carrying FCGR2C-ORF do not express Fc $\gamma$ RIIC due to splice-site mutations and loss of exon 7. Inversely, this polymorphism leads to the expression of inhibitory $h F c \gamma$ RIIB expression on NK cells that has been shown to negatively regulate IgG-induced NK cell activation (17).

\section{Fc $\gamma$ RIIIA}

A SNP determines the presence of a valine or phenylalanine at position 158 (45). The Fc $\gamma$ RIIIA-V 158 variant demonstrates increased affinity for IgG1, IgG2, and IgG3, and increased IgG-induced cell activation and elimination of immune complexes $(8,46,58)$.

\section{FC $\gamma R$ RIIIB}

Fc $\gamma$ RIIIB bears the neutrophil antigen (NA) in its membranedistal Ig-like domain, generating three variants termed NA1 $\left(\mathrm{R}_{36}\right.$ $\left.\begin{array}{lllll}\mathrm{N}_{65} & \mathrm{~A}_{78} & \mathrm{D}_{82} & \mathrm{~V}_{106}\end{array}\right)$, NA2 $\left(\mathrm{S}_{36} \mathrm{~S}_{65} \mathrm{~A}_{78} \mathrm{~N}_{82} \mathrm{I}_{106}\right)(48,59)$, and SH $\left(\begin{array}{lllll}\mathrm{S}_{36} & \mathrm{~S}_{65} & \mathrm{D}_{78} & \mathrm{~N}_{82} & \mathrm{I}_{106}\end{array}\right)$ (50) that do not demonstrate detectable differences in affinity for hIgG subclasses (8). The NA1 allotype was, however, reported to increase phagocytosis of IgG-opsonized particles (49). The SH allotype has been associated with higher Fc $\gamma$ RIIIB expression levels (51).

\section{Gene copy number variation (CNV)}

Recognized as an important indicator for inter-individual differences, can alter the expression of activating IgG receptors. The balance between activating and inhibitory Fc $\gamma$ Rs can therefore be perturbed, altering cellular responses toward IgG-immune complexes. CNV of FCGR2C, FCGR3A, and FCGR3B (Table 1) have been shown to correlate with protein expression levels. Duplications of the gene encoding FCGR3B can lead to the expression of the three different Fc $\gamma$ RIIIB variants (NA1, NA2, and SH) in a single individual (51). CNV in FCGR3A (deletion of one allele) correlated with a reduced expression of Fc $\gamma$ RIIIA on NK cells and impaired cytotoxic function (47). Deletion of a large portion of the FCGR locus, including FCGR2C and FCGR3B, also resulted in abnormal expression of Fc $\gamma$ RIIB on NK cells, presumably due to deletion of upstream regulatory elements. Expression of this inhibitory receptor enabled negative regulation of IgG-induced NK cell activation (17). To the extent of our knowledge, $\mathrm{CNV}$ of the FCGR2A and FCGR2B genes have not been reported (47).

\section{ASSOCIATION WITH DISEASE SUSCEPTIBILITY AND/OR SUCCESS OF ANTIBODY-BASED THERAPIES}

Several FCGR polymorphisms modify the affinity between Fc $\gamma$ Rs and human IgG, and therefore the efficacy of immune complex clearance can be affected. Reduced immune complex clearance is indeed a risk factor for diseases like Systemic Lupus Erythematosus and Wegener's granulomatosis $(60,61)$. Other polymorphisms may favor detrimental inflammatory responses and thus predispose to autoimmunity. Diseases that have been associated with Fc $\gamma \mathrm{R}$ polymorphisms are presented in Table $\mathbf{1}$.

Fc $\gamma R$ polymorphisms may also influence patients' response to treatment with intravenous immunoglobulin and therapeutic $\mathrm{mAb}$. Almost all mAb used in therapy are based on human IgG1 antibodies, either chimeric mouse/human or fully human, allowing their interaction with all human $\mathrm{Fc} \gamma \mathrm{Rs}(8,62)$. The first report to assess the predictive value of $\mathrm{Fc} \gamma \mathrm{R}$ polymorphisms in responses to antibody therapies associated homozygous FCGR3A-V/V 158 individuals with better clinical responses to anti-CD20 therapy (Rituximab) in the treatment of non-Hodgkin lymphomas (63). Homozygous FCGR3A-V/V 158 individuals have since been found to have improved biological responses to anti-CD20 therapy in immune thrombocytopenia (64) and rheumatoid arthritis (RA) (65); and anti-TNF- $\alpha$ therapy (Infliximab) to treat Crohn's disease $(66,67)$; compared to carriers of one or two FCGR3A-F $\mathrm{F}_{158}$ alleles. In arthritis patients, however, findings are controversial regarding the association of FCGR3A polymorphisms with clinical response to TNF- $\alpha$ inhibitors (infliximab, adalimumab, 
etanercept): although one study describes a better clinical response in FCGR3A-F/F $\mathrm{F}_{158}$ patients (68); another, larger study with a more homogenous patient cohort found no association (69). Homozygous FCGR3A-V/V 158 individuals were more likely to experience complete remission from immune thrombocytopenia following medication, but conversely remission rates after splenectomy were higher in homozygous FCGR3A-F/F 158 or heterozygous individuals (70). The FCGR2A-H131 variant associates with susceptibility to Kawasaki Disease (Table 1), whereas responsiveness to IVIG therapy in Kawasaki Disease patients is strongly associated with the FCGR3B genotype: the NA1 variant significantly decreases the odds of an appropriate clinical outcome (71). Similarly, CNV of both FCGR3B and FCGR2C were associated with Kawasaki Disease susceptibility and influenced IVIG treatment response (72). Furthermore, the FCGR2B minor alleles (IIB-386c and IIB-120a) conferring increased promoter activity were positively correlated to IVIG therapeutic response, although with limited statistical power over a small sample size (73). Each of these genetic associations is also constrained by unequal polymorphic variation between the different ethnic groups studied.

Altogether, particular $\mathrm{F} c \gamma \mathrm{R}$ polymorphisms have been described to be associated with the induction or severity of antibody-related disease, or patient responsiveness to antibodybased therapies. Nonetheless one should keep in mind that most Fc $\gamma$ R-encoding genes are located within the 1q23 locus (FCGR2A, FCGR3A, FCGR2B, FCGR2C, FCGR3B) and may display a high degree of linkage disequilibrium, as reported for FCGR2A and FCGR3A (74) and for FCGR2C and FCGR3B (44). Association studies of $\mathrm{Fc} \gamma \mathrm{R}$-encoding genes should therefore include analyses of all Fc $\gamma$ R-encoding genes from the 1q23 locus, and not focus on one particular gene.

\section{IN VIVO ROLES OF HUMAN Fc $\gamma$ RS: LESSONS FROM MOUSE MODELS ${ }^{1}$}

\section{TRANSGENIC MOUSE MODELS EXPRESSING hFc $\gamma \mathrm{R}(\mathrm{s})$}

Transgenic mouse studies have greatly enhanced our understanding of the in vivo function of hFc $\gamma$ Rs. In particular, these studies have highlighted the respective contributions of hFc $\gamma$ Rs to antibody-mediated inflammatory and allergic diseases (refer to Section "Understanding the Role of hFc $\gamma$ Rs In vivo Using Transgenic Mouse Models: Illustrated in Autoimmune, Inflammatory, and Allergic Diseases"). Over the last two decades, various transgenic mouse strains have been generated that carry single or multiple hFc $\gamma$ R-encoding genes (Table 2). Transgenic strains were initially generated on a wild-type mouse background; however, later studies have examined transgene expression in mice deficient for multiple endogenous mFc $\gamma$ Rs, to specifically study the function of the transgenic human receptor.

The common approach to reproduce $h F c \gamma R$ expression patterns in mice is to use the genuine human promoter to drive transgene expression (Table 2). Whereas this strategy was successful for hFc $\gamma$ RIIA $^{\text {tg }}$ and hFc $\gamma$ RIIIB $^{\text {tg }}$ mice, both $h F c \gamma$ RI $^{\text {tg }}$ mice and $h F c \gamma$ RIIB $^{\text {tg }}$ mice exhibit somewhat abnormal expression [discussed in Ref. (62)]. hFc $\gamma \mathrm{RI}^{\mathrm{tg}}$ mice, for example, constitutively

${ }^{1}$ Note: for the sake of clarity, this section will use the terminology " $\mathrm{hFc} \gamma \mathrm{R}$ " for human $\operatorname{IgG}$ receptors, and " $\mathrm{mFc} \gamma \mathrm{R}$ ” for mouse IgG receptors. express substantial amounts of this receptor on neutrophils (37), while in humans $\mathrm{hFc} \gamma \mathrm{RI}$ is only inducibly expressed on neutrophils in contexts of inflammation, infection and during particular therapies [reviewed in Ref. (62)]. An alternative strategy consists of using a cell-specific promoter to drive $\mathrm{hFc} \gamma \mathrm{R}$ expression. $h F c \gamma$ RIIA $^{\text {tg }}, h F c \gamma$ RIIIB $^{\text {tg }}$, or double-transgenic mice were generated using the human MRP8 promoter to express these receptors on neutrophils and, abnormally for $h F c \gamma R$ IIIB, on a proportion of monocytes (34). Finally, efforts made to cross the five single $\mathrm{hFc} \gamma \mathrm{R}$-transgenic mouse strains with $\mathrm{mFc} \gamma \mathrm{R}^{\text {null }}$ mice - lacking $\mathrm{mFc} \gamma \mathrm{RI}, \mathrm{IIB}, \mathrm{III}$, and IV - yielded a mouse model expressing most human IgG receptors - hFc $\gamma$ RI, IIA, IIB, IIIA, and IIIB - that preserves most human expression patterns (119) (Table 2).

\section{UNDERSTANDING THE ROLE OF hFc $\gamma$ Rs IN VIVO USING TRANSGENIC MOUSE MODELS: ILLUSTRATED IN AUTOIMMUNE, INFLAMMATORY, AND ALLERGIC DISEASES}

FcR-mediated uptake of immune complexes and subsequent antigen presentation is a critical aspect of the immune response to foreign pathogens. Targeting of antigen to $h F c \gamma R I$ in $h F c \gamma R I^{t g}$ mice induced a strong antibody response, suggesting that $h F c \gamma R I$ on myeloid cells is capable of mediating antigen uptake and presentation in vivo $(37,120,121)$. Various studies have demonstrated the capacity for $h F c \gamma R I$ and hFc $\gamma$ RIIIA to mediate cytotoxicity in the form of anti-tumor activity when engaged by bi-specific antibodies or antibodies with enhanced FcR binding, highlighting the effectiveness of such engineered antibody therapeutics in vivo (122-125). The role of $\mathrm{Fc} \gamma \mathrm{R}$ in mediating anti-tumor therapies has recently been well-reviewed elsewhere $(126,127)$ and will not be discussed further in this review. $\mathrm{hFc} \gamma \mathrm{R}$-transgenic mice have been useful both in understanding the in vivo function of these receptors and dissecting pathological mechanisms of disease; for illustration this section will describe results obtained in models of autoimmune thrombocytopenia, anaphylaxis, inflammation, and RA. Clearly, the biological responses to immobilized IgG are a function of their location, structure, and deposition, determining the subsequent recruitment and $\mathrm{Fc} \gamma \mathrm{R}$-mediated activation of immune cells: $\mathrm{hFc} \gamma \mathrm{R}$-transgenic mice can assist us also in understanding the cell-specific role of $\mathrm{Fc} \gamma \mathrm{R}$ in recruitment and immune complex clearance.

\section{Autoimmune thrombocytopenia}

Mice deficient for the $\mathrm{FcR} \gamma$-subunit that is necessary for the expression of all mouse activating Fc $\gamma$ Rs are resistant to antibodymediated platelet destruction, demonstrating the importance of activating Fc $\gamma$ Rs in this model of autoimmune thrombocytopenia (128). Using transgenic mice, both $h F c \gamma R I$ and hFc $\gamma$ RIIA were found to be independently sufficient for platelet clearance $(9,129)$. In $\mathrm{hFc} \gamma \mathrm{RI}^{\mathrm{tg}}$ mice, thrombocytopenia was mediated by monocyte/macrophages outside of the spleen (9), whereas in hFc $\gamma$ RIIA $^{\text {tg }}$ mice, splenectomy was found to provoke a more severe phenotype of thrombosis and systemic shock when thrombocytopenia was induced by activating anti-platelet antibodies (130). Importantly, $\mathrm{hFc} \gamma \mathrm{RIIA}$ is the only Fc $\gamma \mathrm{R}$ expressed on platelets, in humans and $h F c \gamma$ RIIA $^{\text {tg }}$ mice. It is likely, therefore, that the presence of this $\mathrm{F} c \gamma \mathrm{R}$ on the platelets themselves contributes to antibody-induced intravascular platelet activation that is most efficiently resolved 
Table 2 | Association of Fc $\gamma$ Rs receptor variants with chronic inflammatory or immunological diseases

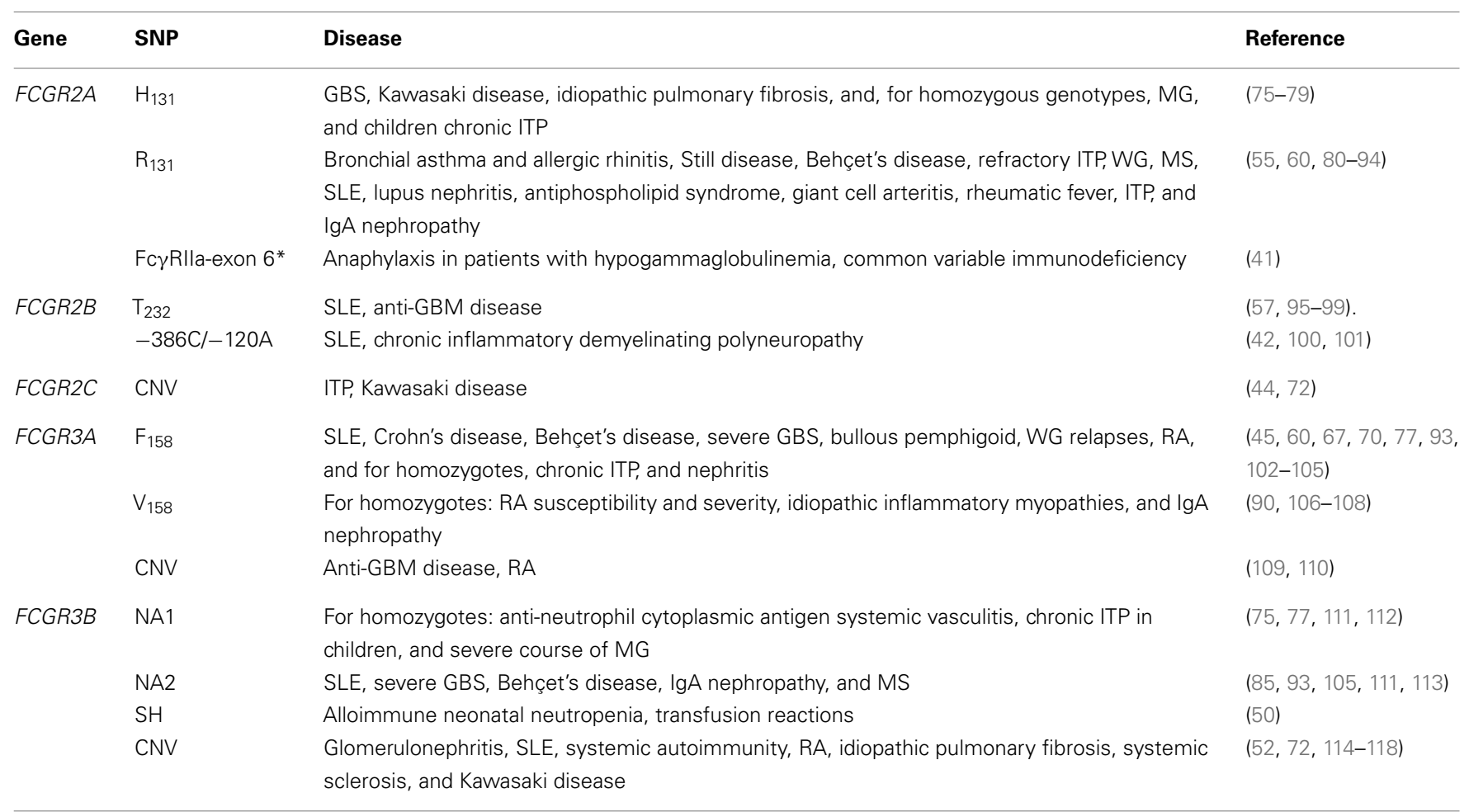

GBM, glomerular basement membrane; GBS, Guillain-Barré syndrome; ITP, idiotypic thrombocytopenic purpura; MG, myasthenia gravis; MS, multiple sclerosis; RA, rheumatoid arthritis; SLE, systemic lupus erythematosis; SNP, single nuclear polymorphism; WG, Wegener's granulomatosis.

by phagocytes in the spleen. These findings have implications for understanding human immune-mediated thrombocytopenic disorders, such as heparin-induced thrombocytopenia/thrombosis (HIT/T), a serious complication arising from the clinical use of heparin. Using $h F c \gamma$ RIIA $^{\text {tg }}$ mice it was identified that antibodies against heparin-platelet factor 4 complexes are responsible for hFc $\gamma$ RIIA-mediated platelet activation, thrombocytopenia, and thrombi formation in the lung vasculature $(131,132)$. Similarly, thromboembolic complications from the use of monoclonal antibody therapies may be a result of $\mathrm{hFc} \gamma \mathrm{RIIA}$-dependent platelet activation due to circulating immune complexes (133, 134). Another important outcome of these mouse studies is that the density of hFc $\gamma$ RIIA expression in the transgenic animal affects the severity of antibody-induced disease (130), which has critical ramifications for understanding differences in immune reactions between individuals. Finally, a therapeutic intervention target-

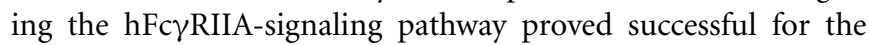
prevention of thrombocytopenia in hFc $\gamma$ RIIA $^{\text {tg }}$ mice (135).

\section{Anaphylactic reactions}

Individuals who have developed antibodies against a given allergen can, upon re-exposure, develop a severe systemic allergic reaction (anaphylaxis). Allergen re-exposure induces the rapid formation of immune complexes that leads to cellular activation and release of vasoactive mediators, which drives the phenotype of systemic shock, including symptoms of hypotension and respiratory distress. Although anaphylaxis is classically attributed to an IgE-mediated mast cell-dependent paradigm of allergic reactivity, the same systemic symptoms can be reproduced experimentally in mice by the transfer of specific IgG antibodies and allergen, of preformed immune complexes (passive systemic anaphylaxis, PSA), or by repeated immunization with an antigen prior to challenge (active systemic anaphylaxis, ASA). hFc $\gamma$ RI and hFc $\gamma$ RIIA expressed in transgenic mice were each individually sufficient to mediate PSA, the symptoms of which may be alleviated by pretreatment with blocking antibodies $(9,136)$. PSA mediated by $\mathrm{hFc} \gamma \mathrm{RIIA}$ was found to be independent of mast cells and basophils, but rather dependent on neutrophils and monocytes/macrophages (136). Furthermore, hFc $\gamma$ RI and hFc $\gamma$ RIIA were identified as each individually sufficient to mediate ASA in transgenic mice, resulting in both hypothermia and death $(9,136)$. hFc $\gamma$ RI-dependent ASA required neutrophils and the release of platelet activating factor (9). These data demonstrate that $h F c \gamma R$ expressed on neutrophils and monocytes can mediate fatal anaphylactic reactions in vivo. Furthermore, in $\mathrm{hFc} \gamma \mathrm{RI}^{\mathrm{tg}} \mathrm{IIA}^{\mathrm{tg}} \mathrm{IIB}^{\mathrm{tg}} \mathrm{IIIA}^{\mathrm{tg}} \mathrm{IIIB}^{\mathrm{tg}}$ mice (on the $\mathrm{mFc} \gamma \mathrm{R}^{\text {null }}$ background), administration of aggregated IgG was sufficient to trigger anaphylaxis (119). In addition, directly targeting either $\mathrm{hFc} \gamma \mathrm{RI}$ or $\mathrm{hFc} \gamma \mathrm{RIIA}$ by injection of agonistic mAb could induce anaphylaxis in transgenic mice $(9,136)$. Altogether, these data support the notion that anaphylaxis may also occur in humans in an hFc $\gamma \mathrm{R}$-dependent manner when allergen-specific IgGs are produced by an individual.

\section{Immune complex induced inflammation}

The formation of immune complexes is a hallmark of many human diseases, and their accumulation is an important trigger of inflammation-induced tissue damage. Pathogenic antibodies may bind directly to host cells, or immune complexes may deposit 
within tissues and trigger activation of local or circulating hFc $\gamma \mathrm{R}$ expressing cells. Using $\mathrm{hFc} \gamma \mathrm{RIIA}^{\mathrm{tg}}$ mice, it was demonstrated that hFc $\gamma$ RIIA expressed on skin mast cells could trigger their activation following intradermal injection of immune complexes resulting in an inflammatory reaction in the skin (136). Inflammation of the airways due to local formation of immune complexes is characterized by granulocyte infiltration, elevated levels of myeloperoxidase, and subsequent damage to the lung epithelium, mimicking symptoms of asthmatic disease in humans. Whereas FcR $\gamma$-subunit ${ }^{-1-}$ mice are resistant to IC-induced airway inflammation, transgenic expression of either $\mathrm{hFc} \gamma \mathrm{RI}$ or $\mathrm{hFc} \gamma \mathrm{RIIA}$ was sufficient to restore this antibody-mediated pathology $(9,136)$.

\section{Rheumatoid arthritis}

Rheumatoid arthritis is an autoimmune disease in which the formation of immune complexes within the joints drives an inflammatory pathology. Autoantibodies directed against joint proteins such as collagen type II or glucose-6-phosphate isomerase (GPI) are found in RA patients, and the arthritis pathology may be modeled in mice by either active immunization with joint-associated components or by passive antibody transfer. $\mathrm{hFcRn}^{\text {tg }}$ mice provided direct evidence for the role of this receptor in serum persistence and transport of antibodies into tissues (23). Indeed, $\mathrm{mFcRn}^{-1-}$ mice are resistant to passive arthritis induction, and transgenic expression of $\mathrm{hFcRn}$ could restore arthritis susceptibility $(137,138)$; suggesting that greater IgG serum persistence may have implications for many autoimmune and inflammatory conditions (139). Surprisingly, transgenic expression of $h F c \gamma$ RIIA-R 131 on a wild-type mouse background was associated with the spontaneous development of an RA-like joint pathology (140). Expression of hFc $\gamma$ RIIA indeed renders mice highly susceptible to various models of arthritis (140,141), even if its expression is purposely restricted to neutrophils (142). Small inhibitors designed to bind antagonistically to $\mathrm{hFc} \gamma \mathrm{RIIA}$ were found to be protective (143), proposing a hFc $\gamma$ R-targeted therapy for RA. Besides hFc $\gamma$ RIIA $^{\text {tg }}$ mice, other hFc $\gamma$ R-transgenic mice do not exhibit spontaneous joint inflammation. Nevertheless, $h F c \gamma \mathrm{RI}^{\mathrm{tg}}$ mice demonstrated that this receptor is sufficient to mediate arthritis induction in transgenic mice, dependent on the presence of both neutrophils and monocytes/macrophages (9). Therapeutic elimination of inflammatory macrophages by an hFc $\gamma \mathrm{RI}$-targeting immunotoxin inhibited the progression of experimental arthritis in $\mathrm{hFc} \gamma \mathrm{RI}^{\mathrm{tg}}$ rats (144), and resolved cutaneous inflammation (145).

\section{Cell-specific function of Fc $\gamma R$}

Studies using $\mathrm{hFc} \gamma \mathrm{R}^{\mathrm{tg}}$ mice have enabled the description of specific in vivo functions not only for these IgG receptors, but also the cells that express them. Neutrophils are a particularly relevant example: the two main human neutrophil IgG receptors, hFc $\gamma$ RIIA and $\mathrm{hFc} \gamma \mathrm{RIIIB}$, were found to individually and cooperatively promote IC-induced neutrophil recruitment and accumulation in the tissues. hFc $\gamma$ RIIA alone, however, promoted associated injury and inflammation in multiple models of antibody-dependent autoimmunity. Importantly, neutrophil recruitment occurred despite the absence of $\mathrm{Fc} \gamma \mathrm{R}$ expression on other cell types such as mast cells and macrophages, indicating a prominent role for hFc $\gamma \mathrm{Rs}$ on neutrophils in IC-induced recruitment (34). Furthermore, specialized functions may be attributed to these two neutrophil Fc $\gamma$ R: hFc $\gamma$ RIIIB seems to play an important role in homeostatic clearance of immune complexes deposited within the vasculature, whereas in a complex environment of immune complex deposition within the tissue and the vasculature, $h F c \gamma$ RIIA was required for the formation of neutrophil extracellular traps (NETs) (146). Collectively, these data in $h F c \gamma R^{\text {tg }}$ mice demonstrate the value of a transgenic approach to appreciate the role of human $\mathrm{Fc} \gamma \mathrm{R}$ and the cells expressing them.

\section{FINAL CONSIDERATIONS}

Although, it is tempting to draw conclusions from genetic association studies performed in humans, it would be overreaching to delineate causal relationships between particular Fc $\gamma \mathrm{R}$ variants and antibody-mediated human disease. Importantly, all the human Fc $\gamma$ R-transgenic mouse strains that have been reported express a single polymorphic variant of each $\mathrm{Fc} \gamma \mathrm{R}$ (Table 3). Thus, no comprehensive study can compare today the properties of a given polymorphism in mouse models of disease. Novel mouse models based on the exchange of the entire FCGR locus with that of humans may allow these comparison studies, or transgenic/knock-in mice expressing different polymorphic variants than the transgenic mice already reported, but remain to be generated. Still, when taking into account published data from both humans and animal models (referenced in Tables 2 and 3 ) several parallel observations have been described:

- Expression of $h F c \gamma$ RIIA $\left(R_{131}\right)$ renders mice susceptible to arthritis and autoimmune pathologies including thrombocytopenia (Table 3); and expression of hFc $\gamma$ RIIA-R $R_{131}$ allotype is similarly associated with inflammatory diseases, thrombocytopenia, and autoimmunity in humans (Table 2). The Fc $\gamma$ RIIaexon $6^{*}$ polymorphic variant, which confers increased neutrophil sensitivity to IgG stimulation (Table 1) was also associated with anaphylactic responses in patients upon IVIG therapy (Table 2); consistent with data obtained in hFc $\gamma$ RIIA $^{\text {tg }}$ mice indicating that neutrophils can contribute to IgG-dependant anaphylaxis mediated by Fc $\gamma$ RIIA.

- The NA1 allotypic variant of Fc $\gamma$ RIIIB confers increased phagocytosis of IgG-immune complexes, and is associated with thrombocytopenia in humans; whereas Fc $\gamma$ RIIIB-NA2 and CNV are associated with inflammatory and autoimmune conditions characterized by immune complex deposition. These data are congruent with findings in NA2-hFc $\gamma$ RIIIB $^{\text {tg }}$ mice (Table 2), demonstrating an important role for this receptor in mediating neutrophil recruitment as well as homeostatic clearance of immune complexes.

While genetic association studies identify important risk factors and inform on the involvement of Fc $\gamma \mathrm{R}$ in human disease; $\mathrm{hFc} \gamma \mathrm{R}^{\mathrm{tg}}$ mice allow us to more precisely dissect pathological mechanisms, and describe the role of human $\mathrm{Fc} \gamma \mathrm{R}$ and the cells expressing them in various clinically relevant pathologies. Together, these data in humans and transgenic models highlight the contribution of $h F c \gamma R$ to antibody-mediated diseases, and open avenues for understanding pathogenic mechanisms. Such data will continue 
Table 3 | hFc $\gamma$ R-transgenic mouse models: description and main results obtained.

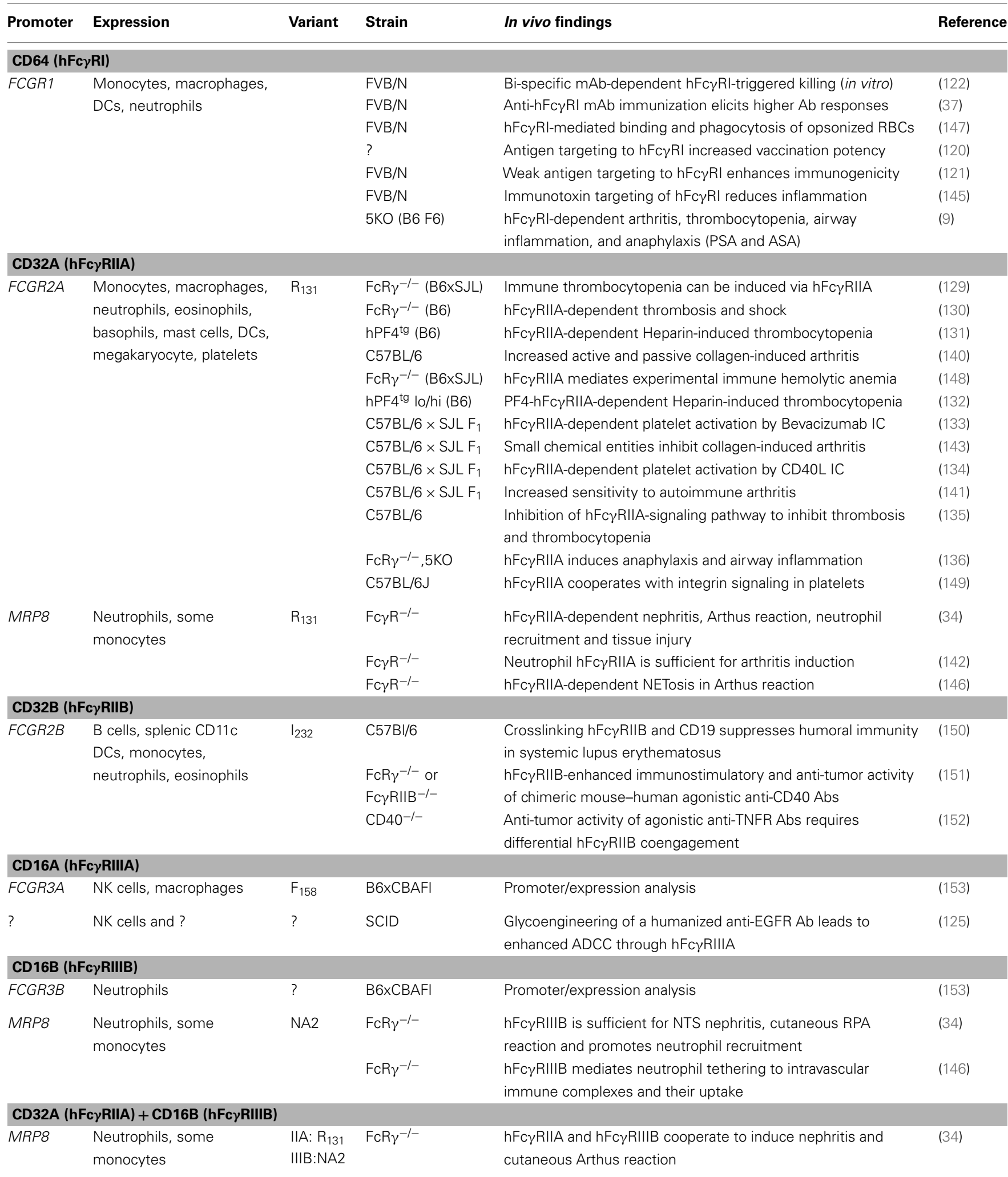


Table 3 | Continued

\begin{tabular}{|c|c|c|c|c|c|}
\hline Promoter & Expression & Variant & Strain & In vivo findings & Reference \\
\hline \multicolumn{6}{|c|}{ Fc $\gamma$ R-HUMANIZED MICE (INTERCROSS OF hFc $\gamma R^{\text {tg }},{ }^{\prime I} A^{t g}, ~ I I B^{t g}, ~ I I I A^{t g}$ AND IIIB ${ }^{\text {tg }}$ MICE) } \\
\hline FCGR1 & \multirow{5}{*}{$\begin{array}{l}\text { Please refer to single } \\
\text { transgenic mice }\end{array}$} & l & \multirow{5}{*}{$\begin{array}{l}\mathrm{mFc} \gamma \mathrm{RI}^{-1-} \\
\mathrm{mFc} \gamma \mathrm{RIIB}^{-1-} \\
\mathrm{mFc} \gamma \mathrm{RIII}^{-1-} \\
\mathrm{mFc} \gamma \mathrm{RIV}^{-1-}\end{array}$} & Antibody-mediated Fc $\gamma$ R-dependent cell depletion (B cells, T & \multirow[t]{5}{*}{ (119) } \\
\hline FCGR2A & & $\| A-R_{131}$ & & cells, platelets), and B16-F10 lung metastasis clearance & \\
\hline FCGR2B & & IIB-I 232 & & Fc $\gamma$ R-mediated IC-induced systemic anaphylaxis & \\
\hline FCGR3A & & $\| \mathrm{II}-\mathrm{F}_{158}$ & & & \\
\hline FCGR3B & & IIIB-? & & & \\
\hline \multicolumn{6}{|l|}{ hFcRn } \\
\hline \multirow[t]{8}{*}{ FCGRT } & \multirow[t]{8}{*}{ Intestine and? } & & $\mathrm{mFcRn}^{-1-}$ & $\begin{array}{l}\text { hFcRn expression restores serum half life of hlgG in } \mathrm{mFcRn}{ }^{-1-} \\
\text { mice }\end{array}$ & $(154)$ \\
\hline & & & $\mathrm{mFcRn}-1-$ & hlgG with engineered high FcRn binding affinity has enhanced & $(137)$ \\
\hline & & & $\mathrm{mFcRn}-1-$ & half life in vivo; inhibition of the binding of pathogenic Abs to & \\
\hline & & & $\mathrm{Fc}_{\mathrm{C}} \mathrm{R} \| \mathrm{B}^{-1-}$ & hFcRn ameliorates arthritis & \\
\hline & & & $\mathrm{mFcRn}-1-$ & Blocking hFcRn using a peptide antagonist increases hlgG & $(155)$ \\
\hline & & & $\mathrm{m} \beta 2 \mathrm{~m}^{-1-}$ & catabolism & \\
\hline & & & $\mathrm{hFCRn}{ }^{\operatorname{tg}} \mathrm{h} \beta 2 \mathrm{~m}^{\mathrm{tg}}$ & & \\
\hline & & & $6 \mathrm{KO}(\mathrm{B} 6 \mathrm{~F} 6)$ & $\mathrm{hFcRn}$ restores arthritis susceptibility in 6KO mice & $(138)$ \\
\hline
\end{tabular}

?, information unavailable in the original publication.

to impact on therapeutic choices and potentially identify new interventional targets.

\section{ACKNOWLEDGMENTS}

Works of our laboratory discussed in this review were supported by the Institut Pasteur, the Institut National de la Santé et de la Recherche Médicale (INSERM), the Agence Nationale pour la Recherche (grant GENOPAT-09-GENO-014-01), the Société Française d'Allergologie (SFA), and the company Balsan. Caitlin Gillis is a scholar of the Pasteur Paris University International Doctoral Program (PPUIDP) and received a stipend from the Institut Carnot Pasteur Maladies Infectieuses. Friederike Jönsson is a chargé de recherche (Investigator) at the Centre National de la Recherche Scientifique (CNRS).

\section{REFERENCES}

1. Wilson TJ, Fuchs A, Colonna M. Cutting edge: human FcRL4 and FcRL5 are receptors for IgA and IgG. J Immunol (2012) 188:4741-5. doi:10.4049/ jimmunol.1102651

2. Franco A, Damdinsuren B, Ise T, Dement-Brown J, Li H, Nagata S, et al. Human Fc receptor-like 5 binds intact IgG via mechanisms distinct from those of Fc receptors. J Immunol (2013) 190:5739-46. doi:10.4049/jimmunol.1202860

3. Yang Y, Eversole T, Lee DJ, Sontheimer RD, Capra JD. Protein-protein interactions between native Ro52 and immunoglobulin G heavy chain. Scand J Immunol (1999) 49:620-8. doi:10.1046/j.1365-3083.1999.00547.x

4. Simister NE, Mostov KE. An Fc receptor structurally related to MHC class I antigens. Nature (1989) 337:184-7. doi:10.1038/337184a0

5. Ober RJ, Martinez C, Vaccaro C, Zhou J, Ward ES. Visualizing the site and dynamics of IgG salvage by the MHC class I-related receptor, FcRn. J Immunol (2004) 172:2021-9. doi:10.4049/jimmunol.172.4.2021

6. James LC, Keeble AH, Khan Z, Rhodes DA, Trowsdale J. Structural basis for PRYSPRY-mediated tripartite motif (TRIM) protein function. Proc Natl Acad Sci US A (2007) 104:6200-5. doi:10.1073/pnas.0609174104

7. Mallery DL, McEwan WA, Bidgood SR, Towers GJ, Johnson CM, James LC. Antibodies mediate intracellular immunity through tripartite motifcontaining 21 (TRIM21). Proc Natl Acad Sci U S A (2010) 107:19985-90. doi:10.1073/pnas.1014074107

8. Bruhns P, Iannascoli B, England P, Mancardi DA, Fernandez N, Jorieux $S$, et al. Specificity and affinity of human Fc\{gamma $\}$ receptors and their polymorphic variants for human IgG subclasses. Blood (2009) 113:3716-25. doi:10.1182/blood-2008-09-179754

9. Mancardi DA, Albanesi M, Jonsson F, Iannascoli B, van Rooijen N, Kang X, et al. The high-affinity human IgG receptor FcgammaRI (CD64) promotes IgGmediated inflammation, anaphylaxis, and antitumor immunotherapy. Blood (2013) 121:1563-73. doi:10.1182/blood-2012-07-442541

10. Ravetch JV, Kinet JP. Fc receptors. Annu Rev Immunol (1991) 9:457-92. doi:10.1146/annurev.iy.09.040191.002325

11. Okayama Y, Kirshenbaum AS, Metcalfe DD. Expression of a functional highaffinity IgG receptor, Fc gamma RI, on human mast cells: up-regulation by IFN-gamma. J Immunol (2000) 164:4332-9. doi:10.4049/jimmunol.164.8. 4332

12. Veri MC, Gorlatov S, Li H, Burke S, Johnson S, Stavenhagen J, et al. Monoclonal antibodies capable of discriminating the human inhibitory Fcgammareceptor IIB (CD32B) from the activating Fcgamma-receptor IIA (CD32A): biochemical, biological and functional characterization. Immunology (2007) 121:392-404. doi:10.1111/j.1365-2567.2007.02588.x

13. Cassard L, Jonsson F, Arnaud S, Daeron M. Fcgamma receptors inhibit mouse and human basophil activation. J Immunol (2012) 189:2995-3006. doi:10.4049/jimmunol.1200968

14. Magnusson SE, Engstrom M, Jacob U, Ulfgren AK, Kleinau S. High synovial expression of the inhibitory FcgammaRIIb in rheumatoid arthritis. Arthritis Res Ther (2007) 9:R51. doi:10.1186/ar2206

15. Zhao W, Kepley CL, Morel PA, Okumoto LM, Fukuoka Y, Schwartz LB. Fc gamma RIIa, not Fc gamma RIIb, is constitutively and functionally expressed on skin-derived human mast cells. J Immunol (2006) 177:694-701. doi:10.4049/jimmunol.177.1.694

16. Metes D, Ernst LK, Chambers WH, Sulica A, Herberman RB, Morel PA. Expression of functional CD32 molecules on human NK cells is determined by an allelic polymorphism of the FcgammaRIIC gene. Blood (1998) 91: 2369-80.

17. van der Heijden J, Breunis WB, Geissler J, De Boer M, van den Berg TK, Kuijpers TW. Phenotypic variation in IgG receptors by nonclassical FCGR2C alleles. J Immunol (2012) 188:1318-24. doi:10.4049/jimmunol.1003945

18. Meknache N, Jönsson F, Laurent J, Guinnepain MT, Daëron M. Human basophils express the glycosylphosphatidylinositol-anchored low-affinity IgG receptor Fc\{gamma\}RIIIB (CD16B). J Immunol (2009) 182:2542-50. doi:10. 4049/jimmunol.0801665

19. Espinosa A, Dardalhon V, Brauner S, Ambrosi A, Higgs R, Quintana FJ, et al. Loss of the lupus autoantigen Ro52/Trim 21 induces tissue inflammation and systemic autoimmunity by disregulating the IL-23-Th17 pathway. J Exp Med (2009) 206:1661-71. doi:10.1084/jem.20090585 
20. Guilliams M, Bruhns P, Saeys Y, Hammad H, Lambrecht BN. The function of Fcgamma receptors in dendritic cells and macrophages. Nat Rev Immunol (2014) 14:94-108. doi:10.1038/nri3582

21. Zhu X, Meng G, Dickinson BL, Li X, Mizoguchi E, Miao L, et al. MHC class I-related neonatal Fc receptor for IgG is functionally expressed in monocytes, intestinal macrophages, and dendritic cells. J Immunol (2001) 166:3266-76. doi:10.4049/jimmunol.166.5.3266

22. Vidarsson G, Stemerding AM, Stapleton NM, Spliethoff SE, Janssen H, Rebers $\mathrm{FE}$, et al. FcRn: an IgG receptor on phagocytes with a novel role in phagocytosis. Blood (2006) 108:3573-9. doi:10.1182/blood-2006-05-024539

23. Roopenian DC, Akilesh S. FcRn: the neonatal Fc receptor comes of age. Nat Rev Immunol (2007) 7:715-25. doi:10.1038/nri2155

24. Smith KG, Clatworthy MR. FcgammaRIIB in autoimmunity and infection: evolutionary and therapeutic implications. Nat Rev Immunol (2010) 10:328-43. doi:10.1038/nri2762

25. Pricop L, Redecha P, Teillaud JL, Frey J, Fridman WH, Sautes-Fridman C, et al. Differential modulation of stimulatory and inhibitory Fc gamma receptors on human monocytes by Th1 and Th2 cytokines. J Immunol (2001) 166:531-7. doi:10.4049/jimmunol.166.1.531

26. van der Poel CE, Karssemeijer RA, Boross P, van der Linden JA, Blokland M, van de Winkel JG, et al. Cytokine-induced immune complex binding to the high-affinity IgG receptor, FcgammaRI, in the presence of monomeric IgG. Blood (2010) 116:5327-33. doi:10.1182/blood-2010-04-280214

27. Daëron M. Fc receptor biology. Annu Rev Immunol (1997) 15:203-34. doi:10. 1146/annurev.immunol.15.1.203

28. Nimmerjahn F, Ravetch JV. Fcgamma receptors as regulators of immune responses. Nat Rev Immunol (2008) 8:34-47. doi:10.1038/nri2206

29. Blank U, Launay P, Benhamou M, Monteiro RC. Inhibitory ITAMs as novel regulators of immunity. Immunol Rev (2009) 232:59-71. doi:10.1111/j.1600065X.2009.00832.x

30. Amigorena S, Bonnerot C, Drake JR, Choquet D, Hunziker W, Guillet JG, et al. Cytoplasmic domain heterogeneity and functions of IgG Fc receptors in B lymphocytes. Science (1992) 256:1808-12. doi:10.1126/science.1535455

31. Ono M, Bolland S, Tempst P, Ravetch JV. Role of the inositol phosphatase SHIP in negative regulation of the immune system by the receptor $\mathrm{Fc}$ (gamma)RIIB. Nature (1996) 383:263-6. doi:10.1038/383263a0

32. Zhu Z, Li R, Li H, Zhou T, Davis RS. FCRL5 exerts binary and compartmentspecific influence on innate-like B-cell receptor signaling. Proc Natl Acad Sci U S A (2013) 110:E1282-90. doi:10.1073/pnas.1215156110

33. Kimberly RP, Ahlstrom JW, Click ME, Edberg JC. The glycosyl phosphatidylinositol-linked Fc gamma RIIIPMN mediates transmembrane signaling events distinct from Fc gamma RII. J Exp Med (1990) 171:1239-55. doi:10.1084/jem.171.4.1239

34. Tsuboi N, Asano K, Lauterbach M, Mayadas TN. Human neutrophil Fcgamma receptors initiate and play specialized nonredundant roles in antibodymediated inflammatory diseases. Immunity (2008) 28:833-46. doi:10.1016/j. immuni.2008.04.013

35. Todd RF III, Petty HR. Beta 2 (CD11/CD18) integrins can serve as signaling partners for other leukocyte receptors. J Lab Clin Med (1997) 129:492-8. doi:10.1016/S0022-2143(97)90003-2

36. McEwan WA, Tam JC, Watkinson RE, Bidgood SR, Mallery DL, James LC. Intracellular antibody-bound pathogens stimulate immune signaling via the Fc receptor TRIM21. Nat Immunol (2013) 14:327-36. doi:10.1038/ni.2548

37. Heijnen IA, van Vugt MJ, Fanger NA, Graziano RF, De Wit TP, Hofhuis FM, et al. Antigen targeting to myeloid-specific human Fc gamma RI/CD64 triggers enhanced antibody responses in transgenic mice. JClin Invest (1996) 97:331-8. doi:10.1172/JCI118420

38. Warmerdam PA, van de Winkel JG, Gosselin EJ, Capel PJ. Molecular basis for a polymorphism of human Fc gamma receptor II (CD32). J Exp Med (1990) 172:19-25. doi:10.1084/jem.172.1.19

39. Parren PW, Warmerdam PA, Boeije LC, Arts J, Westerdaal NA, Vlug A, et al. On the interaction of IgG subclasses with the low affinity Fc gamma RIIa (CD32) on human monocytes, neutrophils, and platelets. Analysis of a functional polymorphism to human IgG2. J Clin Invest (1992) 90:1537-46. doi:10.1172/JCI116022

40. Salmon JE, Edberg JC, Brogle NL, Kimberly RP. Allelic polymorphisms of human $\mathrm{Fc}$ gamma receptor IIA and $\mathrm{Fc}$ gamma receptor IIIB. Independent mechanisms for differences in human phagocyte function. J Clin Invest (1992) 89:1274-81. doi:10.1172/JCI115712
41. van der Heijden J, Geissler J, van Mirre E, van Deuren M, van der Meer JW, Salama A, et al. A novel splice variant of FcgammaRIIa: a risk factor for anaphylaxis in patients with hypogammaglobulinemia. J Allergy Clin Immunol (2013) 131(1408-1416):e1405. doi:10.1016/j.jaci.2013.02.009

42. Su K, Wu J, Edberg JC, Li X, Ferguson P, Cooper GS, et al. A promoter haplotype of the immunoreceptor tyrosine-based inhibitory motif-bearing Fc $\gamma$ RIIb alters receptor expression and associates with autoimmunity. I. Regulatory FCGR2B polymorphisms and their association with systemic lupus erythematosus. J Immunol (2004) 172:7186-91. doi:10.4049/jimmunol.172.11.7186

43. Li X, Wu J, Carter RH, Edberg JC, Su K, Cooper GS, et al. A novel polymorphism in the $\mathrm{Fc} \gamma$ receptor IIB (CD32B) transmembrane region alters receptor signaling. Arthritis Rheum (2003) 48:3242-52. doi:10.1002/art.11313

44. Breunis WB, van Mirre E, Bruin M, Geissler J, De Boer M, Peters M, et al. Copy number variation of the activating FCGR2C gene predisposes to idiopathic thrombocytopenic purpura. Blood (2008) 111:1029-38. doi:10.1182/blood2007-03-079913

45. Wu J, Edberg JC, Redecha PB, Bansal V, Guyre PM, Coleman K, et al. A novel polymorphism of FcgammaRIIIa (CD16) alters receptor function and predisposes to autoimmune disease. J Clin Invest (1997) 100:1059-70. doi:10.1172/JCI119616

46. Ferrara C, Stuart F, Sondermann P, Brunker P, Umana P. The carbohydrate at FcgammaRIIIa Asn-162. An element required for high affinity binding to non-fucosylated IgG glycoforms. J Biol Chem (2006) 281:5032-6. doi:10.1074/jbc.M510171200

47. Breunis WB, van Mirre E, Geissler J, Laddach N, Wolbink G, van der Schoot E, et al. Copy number variation at the FCGR locus includes FCGR3A, FCGR2C and FCGR3B but not FCGR2A and FCGR2B. Hum Mutat (2009) 30:E640-50. doi:10.1002/humu.20997

48. Ory PA, Clark MR, Kwoh EE, Clarkson SB, Goldstein IM. Sequences of complementary DNAs that encode the NA1 and NA2 forms of Fc receptor III on human neutrophils. J Clin Invest (1989) 84:1688-91. doi:10.1172/JCI114350

49. Salmon JE, Edberg JC, Kimberly RP. Fc gamma receptor III on human neutrophils. Allelic variants have functionally distinct capacities. J Clin Invest (1990) 85:1287-95. doi:10.1172/JCI114566

50. Bux J, Stein EL, Bierling P, Fromont P, Clay M, Stroncek D, et al. Characterization of a new alloantigen ( $\mathrm{SH}$ ) on the human neutrophil $\mathrm{Fc}_{\mathrm{c}}$ gamma receptor IIIb. Blood (1997) 89:1027-34.

51. Koene HR, Kleijer M, Roos D, De Haas M, Von Dem Borne AEGK. Fc $\gamma$ RIIIB gene duplication: evidence for presence and expression of three distinct Fc $\gamma$ RIIIB genes in $\mathrm{NA}(1+, 2+) \mathrm{SH}(+)$ individuals. Blood (1998) 91: 673-9.

52. Willcocks LC, Lyons PA, Clatworthy MR, Robinson JI, Yang W, Newland SA, et al. Copy number of FCGR3B, which is associated with systemic lupus erythematosus, correlates with protein expression and immune complex uptake. J Exp Med (2008) 205:1573-82. doi:10.1084/jem.20072413

53. Warmerdam PA, van de Winkel JG, Vlug A, Westerdaal NA, Capel PJ. A single amino acid in the second Ig-like domain of the human $\mathrm{Fc}$ gamma receptor II is critical for human IgG2 binding. J Immunol (1991) 147:1338-43.

54. Osborne JM, Chacko GW, Brandt JT, Anderson CL. Ethnic variation in frequency of an allelic polymorphism of human Fc gamma RIIA determined with allele specific oligonucleotide probes. J Immunol Methods (1994) 173:207-17. doi:10.1016/0022-1759(94)90299-2

55. Lehrnbecher T, Foster CB, Zhu S, Leitman SF, Goldin LR, Huppi K, et al. Variant genotypes of the low-affinity $\mathrm{F} c \gamma$ receptors in two control populations and a review of low-affinity $\mathrm{Fc} \gamma$ receptor polymorphisms in control and disease populations. Blood (1999) 94:4220-32.

56. van der Heijden J, Nagelkerke S, Zhao X, Geissler J, Rispens T, van den Berg TK, et al. Haplotypes of FcgammaRIIa and FcgammaRIIIb polymorphic variants influence IgG-mediated responses in neutrophils. J Immunol (2014) 192(6):2715-21. doi:10.4049/jimmunol.1203570

57. Floto RA, Clatworthy MR, Heilbronn KR, Rosner DR, Macary PA, Rankin A, et al. Loss of function of a lupus-associated Fc[gamma]RIIb polymorphism through exclusion from lipid rafts. Nat Med (2005) 11:1056-8. doi:10.1038/ nm1288

58. Takai T. Fc receptors and their role in immune regulation and autoimmunity. J Clin Immunol (2005) 25:1-18. doi:10.1007/s10875-005-0353-8

59. Huizinga T, Kleijer M, Tetteroo P, Roos D, Von Dem Borne A. Biallelic neutrophil Na-antigen system is associated with a polymorphism on the phosphoinositol-linked Fc gamma receptor III (CD16). Blood (1990) 75:213-7. 
60. Dijstelbloem HM, Scheepers RHM, Oost WW, Stegeman CA, van der Pol WL, Sluiter WJ, et al. Fc $\gamma$ receptor polymorphisms in Wegener's granulomatosis: risk factors for disease relapse. Arthritis Rheum (1999) 42:1823-7. doi:10.1002/ 1529-0131(199909)42:9<1823::AID-ANR5>3.0.CO;2-X

61. Dijstelbloem HM, Bijl M, Fijnheer R, Scheepers RHM, Oost WW, Jansen MD, et al. Fc $\gamma$ receptor polymorphisms in systemic lupus erythematosus: association with disease and in vivo clearance of immune complexes. Arthritis Rheum (2000) 43:2793-800. doi:10.1002/1529-0131(200012)43:12<2793: :AID-ANR20>3.0.CO;2-6

62. Bruhns P. Properties of mouse and human IgG receptors and their contribution to disease models. Blood (2012) 119:5640-9. doi:10.1182/blood-2012-01380121

63. Cartron G, Dacheux L, Salles G, Solal-Celigny P, Bardos P, Colombat P, et al. Therapeutic activity of humanized anti-CD20 monoclonal antibody and polymorphism in IgG Fc receptor FcgammaRIIIa gene. Blood (2002) 99:754-8. doi:10.1182/blood.V99.3.754

64. Cooper N, Stasi R, Cunningham-Rundles S, Cesarman E, McFarland JG, Bussel JB. Platelet-associated antibodies, cellular immunity and FCGR3a genotype influence the response to rituximab in immune thrombocytopenia. $\mathrm{Br}$ J Haematol (2012) 158:539-47. doi:10.1111/j.1365-2141.2012.09184.x

65. Ruyssen-Witrand A, Rouanet S, Combe B, Dougados M, Le Loët X, Sibilia J, et al. Fcy receptor type IIIA polymorphism influences treatment outcomes in patients with rheumatoid arthritis treated with rituximab. Ann Rheum Dis (2012) 71:875-7. doi:10.1136/annrheumdis-2011-200337

66. Louis E, El Ghoul Z, Vermeire S, Dall'ozzo S, Rutgeerts P, Paintaud G, et al. Association between polymorphism in IgG Fc receptor IIIa coding gene and biological response to infliximab in Crohn's disease. Aliment Pharmacol Ther (2004) 19:511-9. doi:10.1111/j.1365-2036.2004.01871.x

67. Moroi R, Endo K, Kinouchi Y, Shiga H, Kakuta Y, Kuroha M, et al. FCGR3A-158 polymorphism influences the biological response to infliximab in Crohn's disease through affecting the ADCC activity. Immunogenetics (2013) 65:265-71. doi:10.1007/s00251-013-0679-8

68. Tutuncu Z, Kavanaugh A, Zvaifler N, Corr M, Deutsch R, Boyle D. Fc $\gamma$ receptor type IIIA polymorphisms influence treatment outcomes in patients with inflammatory arthritis treated with tumor necrosis factor $\alpha$-blocking agents. Arthritis Rheum (2005) 52:2693-6. doi:10.1002/art.21266

69. Kastbom A, Bratt J, Ernestam S, Lampa J, Padyukov L, Söderkvist P, et al. Fc $\gamma$ receptor type IIIA genotype and response to tumor necrosis factor $\alpha$-blocking agents in patients with rheumatoid arthritis. Arthritis Rheum (2007) 56:448-52. doi:10.1002/art.22390

70. Fujimoto T-T, Inoue M, Shimomura T, Fujimura K. Involvement of Fc $\gamma$ receptor polymorphism in the therapeutic response of idiopathic thrombocytopenic purpura. Br J Haematol (2001) 115:125-30. doi:10.1046/j.1365-2141.2001. 03109.x

71. Shrestha S, Wiener H, Shendre A, Kaslow RA, Wu J, Olson A, et al. Role of activating $F c \gamma$ R gene polymorphisms in Kawasaki disease susceptibility and intravenous immunoglobulin response. Circ Cardiovasc Genet (2012) 5:309-16. doi:10.1161/CIRCGENETICS.111.962464

72. Makowsky R, Wiener HW, Ptacek TS, Silva M, Shendre A, Edberg JC, et al. FcgammaR gene copy number in Kawasaki disease and intravenous immunoglobulin treatment response. Pharmacogenet Genomics (2013) 23:455-62. doi:10.1097/FPC.0b013e328363686e

73. Shrestha S, Wiener HW, Olson AK, Edberg JC, Bowles NE, Patel H, et al. Functional FCGR2B gene variants influence intravenous immunoglobulin response in patients with Kawasaki disease. J Allergy Clin Immunol (2011) 128:677-80. doi:10.1016/j.jaci.2011.04.027

74. Lejeune J, Thibault G, Ternant D, Cartron G, Watier H, Ohresser M. Evidence for linkage disequilibrium between Fcgamma RIIIa-V158F and Fcgamma RIIaH131R polymorphisms in white patients, and for an Fcgamma RIIIa-restricted influence on the response to therapeutic antibodies. J Clin Oncol (2008) 26:5489-91. doi:10.1200/JCO.2008.19.4118

75. Raknes G, Skeie GO, Gilhus NE, Aadland S, Vedeler C. Fc $\gamma$ RIIA and Fc $\gamma$ RIIIB polymorphisms in myasthenia gravis. J Neuroimmunol (1998) 81:173-6. doi:10.1016/S0165-5728(97)00174-4

76. van der Pol W-L, van den Berg LH, Scheepers RHM, van der Bom JG, van Doorn PA, van Koningsveld R, et al. IgG receptor IIa alleles determine susceptibility and severity of Guillain-Barré syndrome. Neurology (2000) 54:1661-5. doi:10.1212/WNL.54.8.1661
77. Foster CB, Zhu S, Erichsen HC, Lehrnbecher T, Hart ES, Choi E, et al. Polymorphisms in inflammatory cytokines and $\mathrm{Fc} \gamma$ receptors in childhood chronic immune thrombocytopenic purpura: a pilot study. Br J Haematol (2001) 113:596-9. doi:10.1046/j.1365-2141.2001.02807.x

78. Bournazos S, Grinfeld J, Alexander K, Murchison J, Wallace W, McFarlane P, et al. Association of FcgammaRIIa R131H polymorphism with idiopathic pulmonary fibrosis severity and progression. BMC Pulm Med (2010) 10:51. doi:10.1186/1471-2466-10-51

79. Khor CC, Davila S, Breunis WB, Lee Y-C, Shimizu C, Wright VJ, et al. Genomewide association study identifies FCGR2A as a susceptibility locus for Kawasaki disease. Nat Genet (2011) 43:1241-6. doi:10.1038/ng.981

80. Sanders LAM, van de Winkel JGJ, Rijkers GT, Voorhorst-Ogink MM, De Haas M, Capel PJA, et al. Fcã receptor Iia (Cd32) heterogeneity in patients with recurrent bacterial respiratory tract infections. J Infect Dis (1994) 170:854-61. doi:10.1093/infdis/170.4.854

81. Duits AJ, Bootsma H, Derksen RH, Spronk PE, Kater L, Kallenberg CG, et al. Skewed distribution of IgG Fc receptor IIa (CD32) polymorphism is associated with renal disease in systemic lupus erythematosus patients. Arthritis Rheum (1995) 38:1832-6. doi:10.1002/art.1780381217

82. Edberg JC, Wainstein E, Wu J, Csernok E, Sneller MC, Hoffman GS, et al. Analysis of FcgammaRII gene polymorphisms in Wegener's granulomatosis. Exp Clin Immunogenet (1997) 14:183-95.

83. Haseley LA, Wisnieski JJ, Denburg MR, Michael-Grossman AR, Ginzler EM, Gourley MF, et al. Antibodies to C1q in systemic lupus erythematosus: characteristics and relation to Fc gamma RIIA alleles. Kidney Int (1997) 52:1375-80. doi:10.1038/ki.1997.464

84. Williams Y, Lynch S, McCann S, Smith O, Feighery C, Whelan A. Correlation of platelet Fc $\gamma$ RIIA polymorphism in refractory idiopathic (immune) thrombocytopenic purpura. Br J Haematol (1998) 101:779-82. doi:10.1046/j.13652141.1998.00802.x

85. Myhr K-M, Raknes G, Nyland H, Vedeler C. Immunoglobulin G Fc-receptor $(\mathrm{Fc} \gamma \mathrm{R})$ IIA and IIIB polymorphisms related to disability in MS. Neurology (1999) 52:1771. doi:10.1212/WNL.52.9.1771

86. Norsworthy P, Theodoridis E, Botto M, Athanassiou P, Beynon H, Gordon $\mathrm{C}$, et al. Overrepresentation of the $\mathrm{Fc} \gamma$ receptor type IIA R131/R131 genotype in Caucasoid systemic lupus erythematosus patients with autoantibodies to Clq and glomerulonephritis. Arthritis Rheum (1999) 42:1828-32. doi:10.1002/1529-0131(199909)42:9<1828::AID-ANR6>3.0.CO;2-F

87. Yun HR, Koh HK, Kim SS, Chung WT, Kim DW, Hong KP, et al. FcgammaRIIa/IIIa polymorphism and its association with clinical manifestations in Korean lupus patients. Lupus (2001) 10:466-72. doi:10.1191/ 096120301678416015

88. Karassa FB, Trikalinos TA, Ioannidis JPA. Role of the FC $\gamma$ receptor IIa polymorphism in susceptibility to systemic lupus erythematosus and lupus nephritis: a meta-analysis. Arthritis Rheum (2002) 46:1563-71. doi:10.1002/ art.10306

89. Karassa FB, Bijl M, Davies KA, Kallenberg CGM, Khamashta MA, Manger $\mathrm{K}$, et al. Role of the $\mathrm{F} c \gamma$ receptor IIA polymorphism in the antiphospholipid syndrome: an international meta-analysis. Arthritis Rheum (2003) 48:1930-8. doi:10.1002/art.11059

90. Tanaka Y, Suzuki Y, Tsuge T, Kanamaru Y, Horikoshi S, Monteiro RC, et al. FcgammaRIIa-131R allele and FcgammaRIIIa-176V/V genotype are risk factors for progression of IgA nephropathy. Nephrol Dial Transplant (2005) 20:2439-45. doi:10.1093/ndt/gfi043

91. Morgan AW, Robinson JI, Barrett JH, Martin J, Walker A, Babbage SJ, et al. Association of FCGR2A and FCGR2A-FCGR3A haplotypes with susceptibility to giant cell arteritis. Arthritis Res Ther (2006) 8:R109. doi:10.1186/ar1996

92. Gulen F, Tanac R, Altinoz S, Berdeli A, Zeyrek D, Koksoy H, et al. The Fc $\gamma$ RIIa polymorphism in Turkish children with asthma bronchial and allergic rhinitis. Clin Biochem (2007) 40:392-6. doi:10.1016/j.clinbiochem.2006.11.014

93. Aksu K, Kitapcioglu G, Keser G, Berdeli A, Karabulut G, Kobak S, et al. FcgammaRIIa, IIIa and IIIb gene polymorphisms in Behcet's disease: do they have any clinical implications? Clin Exp Rheumatol (2008) 26:S77-83.

94. Woo J-H, Sung Y-K, Lee J-S, Chung WT, Choe J-Y, Song GG, et al. Association of Fcy receptor polymorphisms with adult onset still's disease in Korea. J Rheumatol (2009) 36:347-50. doi:10.3899/jrheum.071254

95. Kyogoku C, Dijstelbloem HM, Tsuchiya N, Hatta Y, Kato H, Yamaguchi A, et al. Fc $\gamma$ receptor gene polymorphisms in Japanese patients with systemic 
lupus erythematosus: contribution of FCGR2B to genetic susceptibility. Arthritis Rheum (2002) 46:1242-54. doi:10.1002/art.10257

96. Siriboonrit U, Tsuchiya N, Sirikong M, Kyogoku C, Bejrachandra S, Suthipinittharm P, et al. Association of Fcy receptor IIb and IIIb polymorphisms with susceptibility to systemic lupus erythematosus in Thais. Tissue Antigens (2003) 61:374-83. doi:10.1034/j.1399-0039.2003.00047.x

97. Kono H, Kyogoku C, Suzuki T, Tsuchiya N, Honda H, Yamamoto K, et al. FcyRIIB Ile232Thr transmembrane polymorphism associated with human systemic lupus erythematosus decreases affinity to lipid rafts and attenuates inhibitory effects on B cell receptor signaling. Hum Mol Genet (2005) 14:2881-92. doi:10.1093/hmg/ddi320

98. Willcocks LC, Carr EJ, Niederer HA, Rayner TF, Williams TN, Yang W, et al. A defunctioning polymorphism in FCGR2B is associated with protection against malaria but susceptibility to systemic lupus erythematosus. Proc Natl Acad Sci US A (2010) 107:7881-5. doi:10.1073/pnas.0915133107

99. Zhou X-J, Lv J-C, Yu L, Cui Z, Zhao J, Yang R, et al. FCGR2B gene polymorphism rather than FCGR2A, FCGR3A and FCGR3B is associated with anti-GBM disease in Chinese. Nephrol Dial Transplant (2010) 25:97-101. doi:10.1093/ndt/gfp374

100. Blank M, Stefanescu R, Masuda E, Marti F, King P, Redecha P, et al. Decreased transcription of the human FCGR2B gene mediated by the $-343 \mathrm{G} / \mathrm{C}$ promoter polymorphism and association with systemic lupus erythematosus. Hum Genet (2005) 117:220-7. doi:10.1007/s00439-005-1302-3

101. Tackenberg B, Jelcic I, Baerenwaldt A, Oertel WH, Sommer N, Nimmerjahn $\mathrm{F}$, et al. Impaired inhibitory Fc $\gamma$ receptor IIB expression on B cells in chronic inflammatory demyelinating polyneuropathy. Proc Natl Acad Sci U S A (2009) 106:4788-92. doi:10.1073/pnas.0807319106

102. Koene HR, Kleijer M, Swaak AJ, Sullivan KE, Bijl M, Petri MA, et al. The Fc gammaRIIIA-158F allele is a risk factor for systemic lupus erythematosus. Arthritis Rheum (1998) 41:1813-8. doi:10.1002/1529-0131(199810)41: $10<1813::$ AID-ART13>3.3.CO;2-Y

103. Nieto A, Cáliz R, Pascual M, Matarán L, García S, Martín J. Involvement of $\mathrm{Fc} \gamma$ receptor IIIA genotypes in susceptibility to rheumatoid arthritis. Arthritis Rheum (2000) 43:735-9. doi:10.1002/1529-0131(200004)43:4<735::AIDANR3>3.0.CO;2-Q

104. Edberg JC, Langefeld CD, Wu J, Moser KL, Kaufman KM, Kelly J, et al. Genetic linkage and association of Fc $\gamma$ receptor IIIA (CD16A) on chromosome 1q23 with human systemic lupus erythematosus. Arthritis Rheum (2002) 46:2132-40. doi:10.1002/art.10438

105. van Sorge NM, van der Pol WL, Jansen MD, Geleijns KPW, Kalmijn S, Hughes RAC, et al. Severity of Guillain-Barré syndrome is associated with Fc $\gamma$ receptor III polymorphisms. J Neuroimmunol (2005) 162:157-64. doi:10.1016/j. jneuroim.2005.01.016

106. Morgan AW, Griffiths B, Ponchel F, Montague BMN, Ali M, Gardner PP, et al. Fcy receptor type IIIA is associated with rheumatoid arthritis in two distinct ethnic groups. Arthritis Rheum (2000) 43:2328-34. doi:10.1002/15290131(200010)43:10<2328::AID-ANR21>3.0.CO;2-Z

107. Lee YH, Ji JD, Song GG. Associations between FCGR3A polymorphisms and susceptibility to rheumatoid arthritis: a meta analysis. J Rheumatol (2008) 35:2129-35. doi:10.3899/jrheum.080186

108. Bronner IM, Hoogendijk JE, De Visser M, van de Vlekkert J, Badrising UA, Wintzen AR, et al. Association of the leukocyte immunoglobulin G (Fc $\gamma$ ) receptor IIIa-158V/F polymorphism with inflammatory myopathies in Dutch patients. Tissue Antigens (2009) 73:586-9. doi:10.1111/j.1399-0039. 2009.01236.x

109. Thabet MM, Huizinga TWJ, Marques RB, Stoeken-Rijsbergen G, Bakker AM, Kurreeman FA, et al. Contribution of Fc $\gamma$ receptor IIIA gene 158V/F polymorphism and copy number variation to the risk of ACPA-positive rheumatoid arthritis. Ann Rheum Dis (2009) 68:1775-80. doi:10.1136/ard.2008.099309

110. Zhou X-J, Lv J-C, Bu D-F, Yu L, Yang Y-R, Zhao J, et al. Copy number variation of FCGR3A rather than FCGR3B and FCGR2B is associated with susceptibility to anti-GBM disease. Int Immunol (2010) 22:45-51. doi:10.1093/intimm/dxp113

111. Hatta Y, Tsuchiya N, Ohashi J, Matsushita M, Fujiwara K, Hagiwara K, et al. Association of Fc gamma receptor IIIB, but not of $\mathrm{Fc}$ gamma receptor IIA and IIIA polymorphisms with systemic lupus erythematosus in Japanese. Genes Immun (1999) 1:53-60. doi:10.1038/sj.gene.6363639

112. Tse WY, Abadeh S, Jefferis R, Savage CO, Adu D. Neutrophil FcgammaRIIIb allelic polymorphism in anti-neutrophil cytoplasmic antibody
(ANCA)-positive systemic vasculitis. Clin Exp Immunol (2000) 119:574-7. doi:10.1046/j.1365-2249.2000.01182.x

113. Xu G, He Q, Shou Z, Wang H, Zhang X, Wang Y, et al. NA1/NA2 heterozygote of Fcgr3b is a risk factor for progression of IgA nephropathy in Chinese. JClin Lab Anal (2007) 21:298-302. doi:10.1002/jcla.20189

114. Aitman TJ, Dong R, Vyse TJ, Norsworthy PJ, Johnson MD, Smith J, et al. Copy number polymorphism in Fcgr3 predisposes to glomerulonephritis in rats and humans. Nature (2006) 439:851-5. doi:10.1038/nature04489

115. Fanciulli M, Norsworthy PJ, Petretto E, Dong R, Harper L, Kamesh L, et al. FCGR3B copy number variation is associated with susceptibility to systemic, but not organ-specific, autoimmunity. Nat Genet (2007) 39:721-3. doi:10.1038/ng2046

116. Bournazos S, Bournazou I, Murchison JT, Wallace WA, McFarlane P, Hirani $\mathrm{N}$, et al. Copy number variation of $<\mathrm{i}>\mathrm{FCGR} 3 \mathrm{~B}</ \mathrm{i}>$ is associated with susceptibility to idiopathic pulmonary fibrosis. Respiration (2011) 81:142-9. doi:10.1159/000321997

117. Graf SW, Lester S, Nossent JC, Hill CL, Proudman SM, Lee A, et al. Low copy number of the FCGR3B gene and rheumatoid arthritis: a case-control study and meta-analysis. Arthritis Res Ther (2012) 14:R28. doi:10.1186/ar3731

118. McKinney C, Broen JCA, Vonk MC, Beretta L, Hesselstrand R, Hunzelmann N, et al. Evidence that deletion at FCGR3B is a risk factor for systemic sclerosis. Genes Immun (2012) 13:458-60. doi:10.1038/gene.2012.15

119. Smith P, Dilillo DJ, Bournazos S, Li F, Ravetch JV. Mouse model recapitulating human Fcgamma receptor structural and functional diversity. Proc Natl Acad Sci U S A (2012) 109(16):6181-6. doi:10.1073/pnas.1203954109

120. Guyre PM, Graziano RF, Goldstein J, Wallace PK, Morganelli PM, Wardwell $\mathrm{K}$, et al. Increased potency of Fc-receptor-targeted antigens. Cancer Immunol Immunother (1997) 45:146-8. doi:10.1007/s002620050418

121. Keler T, Guyre PM, Vitale LA, Sundarapandiyan K, van de Winkel JG, Deo YM, et al. Targeting weak antigens to CD64 elicits potent humoral responses in human CD64 transgenic mice. J Immunol (2000) 165:6738-42. doi:10.4049/jimmunol.165.12.6738

122. Heijnen IA, van de Winkel JG. A human Fc gamma RI/CD64 transgenic model for in vivo analysis of (bispecific) antibody therapeutics. J Hematother (1995) 4:351-6. doi:10.1089/scd.1.1995.4.351

123. Stavenhagen JB, Gorlatov S, Tuaillon N, Rankin CT, Li H, Burke S, et al. FC optimization of therapeutic antibodies enhances their ability to kill tumor cells in vitro and controls tumor expansion in vivo via low-affinity activating Fcgamma receptors. Cancer Res (2007) 67:8882-90. doi:10.1158/0008-5472. CAN-07-0696

124. Junttila TT, Parsons K, Olsson C, Lu Y, Xin Y, Theriault J, et al. Superior in vivo efficacy of afucosylated trastuzumab in the treatment of HER2-amplified breast cancer. Cancer Res (2010) 70:4481-9. doi:10.1158/0008-5472.CAN-093704

125. Gerdes CA, Nicolini VG, Herter S, van Puijenbroek E, Lang S, Roemmele M, et al. GA201 (RG7160): a novel, humanized, glycoengineered anti-EGFR antibody with enhanced ADCC and superior in vivo efficacy compared with cetuximab. Clin Cancer Res (2013) 19:1126-38. doi:10.1158/1078-0432.CCR-120989

126. Kim JM, Ashkenazi A. Fcgamma receptors enable anticancer action of proapoptotic and immune-modulatory antibodies. J Exp Med (2013) 210:1647-51. doi:10.1084/jem.20131625

127. Mellor JD, Brown MP, Irving HR, Zalcberg JR, Dobrovic A. A critical review of the role of $\mathrm{Fc}$ gamma receptor polymorphisms in the response to monoclonal antibodies in cancer. J Hematol Oncol (2013) 6:1. doi:10.1186/1756-8722-6- 1

128. Clynes R, Ravetch JV. Cytotoxic antibodies trigger inflammation through $\mathrm{Fc}$ receptors. Immunity (1995) 3:21-6. doi:10.1016/1074-7613(95)90155-8

129. McKenzie SE, Taylor SM, Malladi P, Yuhan H, Cassel DL, Chien P, et al. The role of the human $\mathrm{Fc}$ receptor $\mathrm{Fc}$ gamma RIIA in the immune clearance of platelets: a transgenic mouse model. J Immunol (1999) 162:4311-8.

130. Taylor SM, Reilly MP, Schreiber AD, Chien P, Tuckosh JR, McKenzie SE. Thrombosis and shock induced by activating antiplatelet antibodies in human Fc gamma RIIA transgenic mice: the interplay among antibody, spleen, and Fc receptor. Blood (2000) 96:4254-60.

131. Reilly MP, Taylor SM, Hartman NK, Arepally GM, Sachais BS, Cines DB, et al. Heparin-induced thrombocytopenia/thrombosis in a transgenic mouse model requires human platelet factor 4 and platelet activation through FcgammaRIIA. Blood (2001) 98:2442-7. doi:10.1182/blood.V98.8.2442 
132. Rauova L, Zhai L, Kowalska MA, Arepally GM, Cines DB, Poncz M. Role of platelet surface PF4 antigenic complexes in heparin-induced thrombocytopenia pathogenesis: diagnostic and therapeutic implications. Blood (2006) 107:2346-53. doi:10.1182/blood-2005-08-3122

133. Meyer T, Robles-Carrillo L, Robson T, Langer F, Desai H, Davila M, et al. Bevacizumab immune complexes activate platelets and induce thrombosis in FCGR2A transgenic mice. J Thromb Haemost (2009) 7:171-81. doi:10.1111/j. 1538-7836.2008.03212.x

134. Robles-Carrillo L, Meyer T, Hatfield M, Desai H, Davila M, Langer F, et al. Anti-CD40L immune complexes potently activate platelets in vitro and cause thrombosis in FCGR2A transgenic mice. J Immunol (2010) 185:1577-83. doi:10.4049/jimmunol.0903888

135. Stolla M, Stefanini L, Andre P, Ouellette TD, Reilly MP, McKenzie SE, et al. CalDAG-GEFI deficiency protects mice in a novel model of Fcgamma RIIAmediated thrombosis and thrombocytopenia. Blood (2011) 118:1113-20. doi:10.1182/blood-2011-03-342352

136. Jönsson F, Mancardi DA, Zhao W, Kita Y, Iannascoli B, Khun H, et al. Human FcgammaRIIA induces anaphylactic and allergic reactions. Blood (2012) 119:2533-44. doi:10.1182/blood-2011-07-367334

137. Petkova SB, Akilesh S, Sproule TJ, Christianson GJ, Al Khabbaz H, Brown AC, et al. Enhanced half-life of genetically engineered human IgG1 antibodies in a humanized FcRn mouse model: potential application in humorally mediated autoimmune disease. Int Immunol (2006) 18:1759-69. doi:10.1093/intimm/ dxl110

138. Mancardi DA, Jonsson F, Iannascoli B, Khun H, van Rooijen N, Huerre $\mathrm{M}$, et al. The murine high-affinity IgG receptor $\mathrm{Fc}$ (gamma)RIV is sufficient for autoantibody-induced arthritis. J Immunol (2011) 186:1899-903. doi:10.4049/jimmunol.1003642

139. Christianson GJ, Blankenburg RL, Duffy TM, Panka D, Roths JB, MarshakRothstein A, et al. beta2-microglobulin dependence of the lupus-like autoimmune syndrome of MRL-lpr mice. J Immunol (1996) 156:4932-9.

140. Tan Sardjono C, Mottram PL, van de Velde NC, Powell MS, Power D, Slocombe RF, et al. Development of spontaneous multisystem autoimmune disease and hypersensitivity to antibody-induced inflammation in Fcgamma receptor IIatransgenic mice. Arthritis Rheum (2005) 52:3220-9. doi:10.1002/art.21344

141. van de Velde NC, Mottram PL, Powell MS, Lim B, Holmdahl R, Hogarth PM. Transgenic mice expressing human FcgammaRIIa have enhanced sensitivity to induced autoimmune arthritis as well as elevated Th17 cells. Immunol Lett (2010) 130:82-8. doi:10.1016/j.imlet.2009.12.005

142. Tsuboi N, Ernandez T, Li X, Nishi H, Cullere X, Mekala D, et al. Regulation of human neutrophil Fcgamma receptor IIa by C5a receptor promotes inflammatory arthritis in mice. Arthritis Rheum (2011) 63:467-78. doi:10.1002/ art.30141

143. Pietersz GA, Mottram PL, van de Velde NC, Sardjono CT, Esparon S, Ramsland PA, et al. Inhibition of destructive autoimmune arthritis in FcgammaRIIa transgenic mice by small chemical entities. Immunol Cell Biol (2009) 87:3-12. doi:10.1038/icb.2008.82

144. van Vuuren AJ, van Roon JA, Walraven V, Stuij I, Harmsen MC, McLaughlin PM, et al. CD64-directed immunotoxin inhibits arthritis in a novel CD64 transgenic rat model. J Immunol (2006) 176:5833-8. doi:10.4049/jimmunol.176.10.5833

145. Thepen T, van Vuuren AJ, Kiekens RC, Damen CA, Vooijs WC, van de Winkel JG. Resolution of cutaneous inflammation after local elimination of macrophages. Nat Biotechnol (2000) 18:48-51. doi:10.1038/71908
146. Chen K, Nishi H, Travers R, Tsuboi N, Martinod K, Wagner DD, et al. Endocytosis of soluble immune complexes leads to their clearance by FcgammaRIIIB but induces neutrophil extracellular traps via FcgammaRIIA in vivo. Blood (2012) 120:4421-31. doi:10.1182/blood-2011-12-401133

147. van Vugt MJ, Heijnen AF, Capel PJ, Park SY, Ra C, Saito T, et al. FcR gammachain is essential for both surface expression and function of human Fc gamma RI (CD64) in vivo. Blood (1996) 87:3593-9.

148. van Royen-Kerkhof A, Sanders EA, Walraven V, Voorhorst-Ogink M, Saeland E, Teeling JL, et al. A novel human CD32 mAb blocks experimental immune haemolytic anaemia in FcgammaRIIA transgenic mice. Br J Haematol (2005) 130:130-7. doi:10.1111/j.1365-2141.2005.05571.x

149. Zhi H, Rauova L, Hayes V, Gao C, Boylan B, Newman DK, et al. Cooperative integrin/ITAM signaling in platelets enhances thrombus formation in vitro and in vivo. Blood (2013) 121:1858-67. doi:10.1182/blood-2012-07-443325

150. Horton HM, Chu SY, Ortiz EC, Pong E, Cemerski S, Leung IW, et al. Antibodymediated coengagement of FcgammaRIIb and B cell receptor complex suppresses humoral immunity in systemic lupus erythematosus. J Immunol (2011) 186:4223-33. doi:10.4049/jimmunol.1003412

151. Li F, Ravetch JV. Inhibitory Fcgamma receptor engagement drives adjuvant and anti-tumor activities of agonistic CD40 antibodies. Science (2011) 333:1030-4. doi:10.1126/science. 1206954

152. Li F, Ravetch JV. Antitumor activities of agonistic anti-TNFR antibodies require differential FcgammaRIIB coengagement in vivo. Proc Natl Acad Sci U S A (2013) 110:19501-6. doi:10.1073/pnas.1319502110

153. Li M, Wirthmueller U, Ravetch JV. Reconstitution of human Fc gamma RIII cell type specificity in transgenic mice. J Exp Med (1996) 183:1259-63. doi:10.1084/jem.183.3.1259

154. Roopenian DC, Christianson GJ, Sproule TJ, Brown AC, Akilesh S, Jung N, et al. The MHC class I-like IgG receptor controls perinatal IgG transport, IgG homeostasis, and fate of IgG-Fc-coupled drugs. J Immunol (2003) 170:3528-33. doi:10.4049/jimmunol.170.7.3528

155. Mezo AR, McDonnell KA, Hehir CA, Low SC, Palombella VJ, Stattel JM, et al. Reduction of $\operatorname{IgG}$ in nonhuman primates by a peptide antagonist of the neonatal Fc receptor FcRn. Proc Natl Acad Sci U S A (2008) 105:2337-42. doi:10.1073/pnas.0708960105

Conflict of Interest Statement: The authors declare that the research was conducted in the absence of any commercial or financial relationships that could be construed as a potential conflict of interest.

Received: 11 March 2014; paper pending published: 29 March 2014; accepted: 14 May 2014; published online: 30 May 2014.

Citation: Gillis C, Gouel-Chéron A, Jönsson F and Bruhns P (2014) Contribution of human $F \mathrm{c} \gamma$ Rs to disease with evidence from human polymorphisms and transgenic animal studies. Front. Immunol. 5:254. doi: 10.3389/fimmu.2014.00254

This article was submitted to Immunotherapies and Vaccines, a section of the journal Frontiers in Immunology.

Copyright () 2014 Gillis, Gouel-Chéron, Jönsson and Bruhns. This is an open-access article distributed under the terms of the Creative Commons Attribution License (CC BY). The use, distribution or reproduction in other forums is permitted, provided the original author(s) or licensor are credited and that the original publication in this journal is cited, in accordance with accepted academic practice. No use, distribution or reproduction is permitted which does not comply with these terms. 